\title{
Net community metabolism of a Posidonia oceanica meadow
}

\author{
Willy Champenois (1), Alberto V. Borges (1)* \\ University of Liège, Chemical Ocenography Unit, Liège, Belgium
}

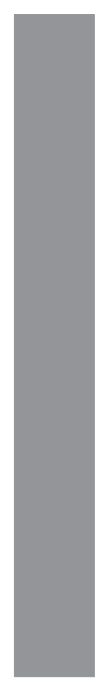

\begin{abstract}
We report a 12-yr data set (August 2006-October 2018) of nearly continuous estimates $(n=3275)$ of gross primary production (GPP), community respiration (CR), and net community production (NCP) in a Posidonia oceanica seagrass meadow, computed from $\mathrm{O}_{2}$ measurements on a mooring at $10 \mathrm{~m}$ bottom depth in the Bay of Revellata (Corsica). Both NCP and CR were correlated to GPP and followed the leaf biomass seasonal cycle. The meadow was net autotrophic (NCP of $23 \pm 8 \mathrm{~mol} \mathrm{O}_{2} \mathrm{~m}^{-2} \mathrm{yr}^{-1}$, GPP $\left[83 \pm 16 \mathrm{moll}_{2} \mathrm{~m}^{-2} \mathrm{yr}^{-1}\right]>-\mathrm{CR}$ $\left.\left[-60 \pm 9 \mathrm{~mol} \mathrm{O}_{2} \mathrm{~m}^{-2} \mathrm{yr}^{-1}\right]\right)$, in agreement with oxygen oversaturation (104\% at annual scale, $101 \%$ in winter, and $109 \%$ in summer). Calcification (CAL) and $\mathrm{CaCO}_{3}$ dissolution (DIS) rates were evaluated from dissolved inorganic carbon measurements in benthic chamber incubations (August 2006-2009). The meadow was found to be a net sink of $\mathrm{CaCO}_{3}$ (DIS > CAL) at an annual rate of $7 \mathrm{~mol} \mathrm{CaCO}_{3} \mathrm{~m}^{-2} \mathrm{yr}^{-1}$ that matched estimates of $\mathrm{CaCO}_{3}$ deposition on the meadow by sedimentation from the water column. CAL from epiphyte coralline algae was correlated to GPP, but CAL : GPP ratio (0.1) was lower than reported for coralline algae in cultures (0.6) due to the additional contribution of Posidonia to GPP. Both NCP and net DIS contributed to an annual $\mathrm{CO}_{2}$ sink of $-30 \mathrm{~mol} \mathrm{CO} \mathrm{Cm}^{-2} \mathrm{yr}^{-1}$ distinctly stronger than the estimated net air-sea $\mathrm{CO}_{2}$ flux $\left(-1 \mathrm{~mol} \mathrm{CO}_{2} \mathrm{~m}^{-2} \mathrm{yr}^{-1}\right)$. This suggests that $\mathrm{CO}_{2}$ input by vertical mixing and/or transport by horizontal advection also strongly contribute to the net atmospheric $\mathrm{CO}_{2}$ exchange.
\end{abstract}

The balance at community scale between gross primary production (GPP) and community respiration (CR, negative flux) is net community production $(\mathrm{NCP}=\mathrm{GPP}+\mathrm{CR})$ and reflects whether a community is net autotrophic $(\mathrm{NCP}>0$, $\mathrm{GPP}>\mathrm{CR}) \quad$ or net heterotrophic $(\mathrm{NCP}<0, \quad \mathrm{GPP}<\mathrm{CR})$ (Supporting Information Fig. S1). This is an important metric to describe organic matter flows in marine communities, because a net autotrophic community is a net producer of organic matter and either stores or exports organic matter to adjacent communities, while a net heterotrophic community is a net consumer of organic matter that is sustained by inputs of organic matter from adjacent communities. In theory, a net autotrophic community should act as a sink of atmospheric $\mathrm{CO}_{2}$, and a net heterotrophic community should act as a source of $\mathrm{CO}_{2}$ to the atmosphere, although, in practice, this is rarely the case because $\mathrm{CO}_{2}$ in seawater will also depend on other biological processes such as calcification (CAL), as well on a variety of other processes such as horizontal (advection) and vertical (mixing) transport of $\mathrm{CO}_{2}$ (Borges et al. 2006). Among coastal systems, estuaries are in majority net heterotrophic, while mangroves, salt-marshes, coral reefs, macrophyte-

*Correspondence: alberto.borges@uliege.be

Additional Supporting Information may be found in the online version of this article. dominated communities, and the rest of continental shelves are in majority net autotrophic (Gattuso et al. 1998).

Marine phanerogams are macrophytes of terrestrial origin that spend their entire life cycle submerged in the ocean and form extensive meadows. In seagrass meadows, there are two main primary producer compartments: the seagrass itself and epiphytic algae, and a smaller compartment related to microphytobenthos on the sediment and on the seagrass shoots. Epiphytic algae contribute between $20 \%$ and $60 \%$ of total seagrass meadow primary production (Marbà et al. 2006). Regarding the fate of seagrass biomass, only $10 \%$ is lost through direct grazing (Cebrián and Duarte 1998) and the majority of the biomass loss is through shedding of leaves that contribute to other detritus (organic particles from the water column plus animal feces) collectively called "litter." Seagrass litter is the main transfer pathway to secondary production through detritivory and to adjacent communities through physical transport (Cebrián and Duarte 1998).

Posidonia oceanica is a seagrass endemic of the Mediterranean Sea that grows in mono-specific meadows that occasionally extend down to $40 \mathrm{~m}$ deep. These meadows cover a surface estimated between 12,000 and $50,000 \mathrm{~km}^{2}$ corresponding to $0.5 \%$ to $2.0 \%$ of the total surface of the Mediterranean Sea and $2.5 \%$ to $10.0 \%$ of its continental shelf (Telesca et al. 2015). The extent and density of $P$. oceanica meadows is declining in the Mediterranean Sea due to degradation of water quality, although the 
rate of decline is very uncertain (Telesca et al. 2015; de los Santos et al. 2019). P. oceanica meadows function as a spawning ground, a nursery and habitat for about 400 plant species and thousands of animal species, in total representing approximately $20 \%$ of the species in the Mediterranean Sea (Boudouresque 2006).

Primary production in seagrass meadows can be measured using different techniques. The oldest techniques were based on measuring the change of leaf biomass either at the level of a single leaf with a marking technique (Zieman 1974), of a shoot based on a lepidochronological analysis (Pergent and Pergent-Martini 1991), or of a meadow patch based on a harvesting technique (Bay 1984). These techniques only provide the leaf net biomass accumulation or growth and do not account for other components of NCP such as biomass burial in sediments or export to adjacent systems, and are destructive. Incubations with radioactive $\left({ }^{14} \mathrm{C}\right)$ or stable $\left({ }^{13} \mathrm{C}\right)$ carbon isotope tracers allow to measure primary production (Mateo et al. 2001) but CR needs to be measured by additional parallel incubations. Such an approach is usually made with ex situ incubations and does not allow accounting for the production of dissolved organic carbon (DOC) that could represent a significant portion of NCP (Barrón and Duarte 2009). DOC exudation from seagrass occurs mostly during the day (Penhale and Smith 1977) and fuels microbial respiration in the rhizosphere and water column (Moriarty et al. 1986). To derive whole community metabolism and measure individually GPP and CR several techniques are based on mass balancing $\mathrm{O}_{2}$ or $\mathrm{CO}_{2}$ fluxes that can be categorized into discrete and near-continuous. The incubation with a benthic chamber is a discrete method based on measuring the change during $24 \mathrm{~h}$ of $\mathrm{O}_{2}$ or $\mathrm{CO}_{2}$ in a very small isolated portion of the community $\left(\sim 0.01 \mathrm{~m}^{2}\right)$ (Barrón et al. 2006; Champenois and Borges 2012). This method is intrusive, time-consuming, and can lead to several artifacts linked to physical disturbance of sediments and damage of plant roots and rhizomes or to abnormally high accumulation of $\mathrm{O}_{2}$ within the chamber (Champenois and Borges 2012). Near-continuous methods are based on the direct measurement of $\mathrm{O}_{2}$ or $\mathrm{CO}_{2}$ in the water column and allow to integrate CR and GPP over larger surfaces $\left(>100 \mathrm{~m}^{2}\right)$ in a nonintrusive way. These techniques are routinely used by mass balancing changes of $\mathrm{O}_{2}$ concentration (Odum 1956) measured by optodes on a mooring (Champenois and Borges 2012, 2019) or by directly determining the $\mathrm{O}_{2}$ fluxes by eddy-covariance (Long et al. 2015; Koopmans et al. 2020). With available technology and sensors, eddy-covariance measurements are limited to short deployments ( $<1$ week) while optodes can be maintained on a mooring for years with minimal maintenance. Both techniques might underestimate GPP because they do not account for $\mathrm{O}_{2}$ in the form of small bubbles either accumulated in aerenchyma or released from the surface of leaves. The presence of bubbles can be continuously detected with acoustic techniques although not quantitatively (Felisberto et al. 2015), and bubble release can be discretely quantified with funnel traps (Long et al. 2020). However, small bubble formation on the surface of leaves only occurs in extremely well illuminated conditions, typically at water depths around $\sim 0.5 \mathrm{~m}$ (Long et al. 2020).

The present study is in continuity of two previous analysis of community metabolism based on the $\mathrm{O}_{2}$ mass balance (Odum 1956) using a mooring equipped by three optodes at $10 \mathrm{~m}$ depth in a $P$. oceanica seagrass meadow in the Bay of Revellata in Corsica (Champenois and Borges 2012, 2019). The first study reported GPP, CR, and NCP during 3 years (2006-2009) and focused on the comparison of metabolic measurements derived from the mooring measurements and parallel benthic incubations, as well as, on the effect of the mild winter of 2006-2007 on NCP (Champenois and Borges 2012). The second study focused only on GPP and showed there were marked inter-annual variations of GPP for the 2006-2016 period that were attributed to year-to-year differences in wintertime storms, light availability, and water temperature (Champenois and Borges 2019). The present study allows to extend the period of analysis to 12 years (2006-2018) and focuses on determining the full budget of carbon in the seagrass meadow both related to the "organic metabolism" (GPP, CR, NCP) and the "inorganic metabolism" related to $\mathrm{CaCO}_{3}$ precipitation (CAL) and dissolution (DIS), that is compared to the air-sea exchange of $\mathrm{CO}_{2}$ derived from measurements on a mooring of the partial pressure of $\mathrm{CO}_{2}\left(\mathrm{pCO}_{2}\right)$.

\section{Material and methods}

\section{Site description}

The Bay of Revellata is located in North-Western Corsisa (France), and is open North-Eastwards, hence, is protected from the dominant local wind (Libeccio). The deepest part of the bay is $100 \mathrm{~m}$ and the average slope of the seafloor is $2 \%$. The P. oceanica meadow is present continuously between 5 and $38 \mathrm{~m}$ depth (small isolated patches can be found up to $2 \mathrm{~m}$ depth). Maps of the coverage of $P$. oceanica meadows as well as other benthic communities in the Bay of Revellata are given in Champenois and Borges (2012) and Velimirov et al. (2016). Moorings $\left(42.5800^{\circ} \mathrm{N}\right.$ $\left.8.7251^{\circ} \mathrm{E}\right)$ were deployed at $10 \mathrm{~m}$ depth at proximity of the STARESO research station, and benthic incubations (10 $\mathrm{m}$ depth), pore-water sampling $\left(8 \mathrm{~m}\right.$ depth) and $\mathrm{CH}_{4}$ sampling in surface waters were carried out close to the moorings.

\section{Moorings}

In August 2006 we deployed two moorings at $10 \mathrm{~m}$ bottom depth at a distance of $5 \mathrm{~m}$ from each other. One mooring was equipped with three optodes for dissolved $\mathrm{O}_{2}$ measurements and water temperature (Aanderra 3835) at three depths (4.5, 7.0, and $9.5 \mathrm{~m}$ ). This mooring was maintained until October 2018. The measurements were interrupted for a few days every 3 months for maintenance and calibration of the optodes, as explained in detail by Champenois and Borges (2012). 
A second mooring was deployed for measurements of the $\mathrm{pCO}_{2}$ in seawater with a Pro-Oceanus CO2-Pro from ProOceanus Systems Inc. that was powered with an external battery pack. The instrument and battery pack were placed on the seafloor at $10 \mathrm{~m}$ depth at $5 \mathrm{~m}$ distance from the optode mooring, and water was pumped into the instrument with a Seabird SBE 5T Pump from a depth of $2 \mathrm{~m}$ with a tube attached to a floater. This mooring was deployed in August 2006 and acquired data until August 2007, when it was retrieved.

\section{Benthic incubations}

From August 2006 to August 2009, we carried out 15 benthic incubations at $10 \mathrm{~m}$ depth within a radius of approximately $20 \mathrm{~m}$ of the optode mooring (Supporting Information Table S1). The benthic chambers consisted of a polyvinyl chloride (PVC) cylindrical base $(9 \mathrm{~cm}$ internal diameter, $25 \mathrm{~cm}$ internal length) and a Plexiglas cylinder $(9 \mathrm{~cm}$ internal diameter, $61 \mathrm{~cm}$ internal length). We used three benthic chambers as replicates. The day before the start of the incubation, the PVC bases were inserted about $15 \mathrm{~cm}$ deep into the vegetated sediment, in three random spots, by underwater divers. At dawn of the next day, the Plexiglass chambers were fixed on the PVC bases. On average, six P. oceanica shoots were enclosed in each chamber. A water pump plugged to the chamber was used during $7 \mathrm{~min}$ to homogenize the water within the chamber prior to sampling, and remained stopped until the next sampling. Three samplings were made at dawn (T0), at dusk (T1), and at dawn $24 \mathrm{~h}$ later (T2), and each time eight polypropylene syringes of $60 \mathrm{~mL}$ were sampled from inside the chamber as well as outside water to compute the dilution of chamber water by outside water at each sampling (given the chamber volume is fixed because the chamber is rigid). Immediately after the end of the dive, the content of the syringes was transferred to a biological oxygen demand (BOD) bottle of $60 \mathrm{~mL}$ to which the two Winkler reagents were added. Then, $\mathrm{pH}$ was measured and $100 \mathrm{~mL}$ of water were filtered with $0.2-\mu \mathrm{m}$ porosity polyethersulfone syringe filters and stored in polyethylene bottles for the determination of total alkalinity (TA). At the end of the incubation, the $P$. oceanica shoots were harvested for the determination of leaf biomass. The shoots were rinsed with freshwater, the length and width measured, the epiphytes scrapped with a razor blade and dry weight determined after drying in an oven during $48 \mathrm{~h}$ at $60^{\circ} \mathrm{C}$. The shoot density was computed from the count of $P$. oceanica shoots within a frame $(25 \mathrm{~cm} \times 40 \mathrm{~cm})$ thrown randomly (10-15 times) within a $20 \mathrm{~m}$ radius of incubation site.

\section{Pore-water sampling}

Pore water was sampled for the determination of $\mathrm{H}_{2} \mathrm{~S}$ and $\mathrm{O}_{2}$ requiring relatively large amounts of water, so the sampling depths in the sediment were very coarse (within the top $0.5,10$, and $20 \mathrm{~cm}$ ). We used home-made needles in stainless steel with a $2 \mathrm{~mm}$ internal diameter ( $3 \mathrm{~mm}$ external diameter). The tip that was inserted in the sediment was stoppered but had two lateral slits of $3 \mathrm{~mm}$ length to allow pore water to enter and the other end was plugged to a polypropylene syringe of $60 \mathrm{~mL}$. Sampling was done by underwater divers in vegetated sediment and bare sediment at $8 \mathrm{~m}$ bottom depth close to the mooring site. The stainless steel needles plugged to the syringes were pushed into the sediment to desired depth and spaced $50 \mathrm{~cm}$ from each other. The needle and syringe were first rinsed and flushed with $5 \mathrm{~mL}$ of pore water. Then the syringes were filled sequentially by $10 \mathrm{~mL}$ increments separated by 2-min intervals. After the dive, for each depth, the content of the syringe was transferred to two 60-mL BOD bottles, and fixed with a $\mathrm{Zn}$ acetate solution for $\mathrm{H}_{2} \mathrm{~S}$ and Winkler reagents for $\mathrm{O}_{2}$.

\section{Methane sampling}

Samples for the determination of dissolved $\mathrm{CH}_{4}$ concentration were collected in surface waters $(\sim 1 \mathrm{~m})$ with polypropylene syringes of $60 \mathrm{~mL}$ by scuba divers along a bathymetric transect from 10 to $30 \mathrm{~m}$ depth. After the dive, the content of the syringes was transferred to two $60-\mathrm{mL}$ borosilicate serum bottles, poisoned with an $\mathrm{HgCl}_{2}$ saturated solution $(100 \mu \mathrm{L})$, sealed with butyl stoppers and crimped with an aluminum caps. Samples were stored in the dark at room temperature until analysis.

\section{Laboratory analysis}

Oxygen was measured by Winkler titration with a potentiometric end-point determination using the protocol, reagents, and calibrations given by Knap et al. (1996), with a precision of $\pm 1 \mu \mathrm{mol} \mathrm{kg}-1$ and an estimated accuracy of $\pm 5 \mu \mathrm{mol} \mathrm{kg}-1$.

$\mathrm{pH}$ was measured with a glass electrode (Metrohm 6.0232.100) calibrated on the Total Hydrogen Ion Concentration Scale with 2-amino-2-hydroxymethyl-1,3-propanediol and 2-aminopyridine buffers prepared in artificial seawater with a salinity of 38 (Dickson 1993), with an accuracy of $\pm 0.004 \mathrm{pH}$ units.

TA was measured by titration with $\mathrm{HCl} 0.1 \mathrm{M}$, and data were quality checked with Certified Reference Material acquired from Andrew Dickson (Scripps Institution of Oceanography, University of California, San Diego), with a precision of $\pm 2 \mu \mathrm{mol} \mathrm{kg}^{-1}$ and an estimated accuracy of $\pm 4 \mu \mathrm{mol} \mathrm{kg}^{-1}$.

$\mathrm{H}_{2} \mathrm{~S}$ was measured with the Cline (1969) colorimetric method based on spectrophotometeric absorption measurements at $670 \mathrm{~nm}$ after addition of a solution of sulfate $\mathrm{N}-\mathrm{N}$ dimethyl-p-phenylenediamine in presence of $\mathrm{FeCl}_{3}$ in a $6 \mathrm{M}$ $\mathrm{HCl}$ solution. The calibration was made with a solution of $\mathrm{Na}_{2} \mathrm{~S}\left(9 \mathrm{H}_{2} \mathrm{O}\right)$ standardized with $\mathrm{KH}\left(\mathrm{IO}_{3}\right)_{2}$.

$\mathrm{CH}_{4}$ was measured by headspace technique $\left(20 \mathrm{~mL} \mathrm{~N}_{2}\right.$ headspace in $60-\mathrm{mL}$ serum bottles) with a gas chromatograph (SRI 8610C) with flame ionization detection calibrated with $\mathrm{CH}_{4}: \mathrm{CO}_{2}: \mathrm{N}_{2} \mathrm{O}: \mathrm{N}_{2}$ mixtures (Air Liquide Belgium) of 1, 10, 
and $30 \mathrm{ppm} \mathrm{CH}_{4}$, with a precision of $\pm 3.9 \%$, and an accuracy better than $\pm 10 \%$ (Wilson et al. 2018).

\section{Metabolic calculations and statistical analysis}

Optodes measure and log the oxygen saturation level (\% $\mathrm{O}_{2}$ ), and the $\mathrm{O}_{2}$ dissolved concentrations were computed from the saturation level given by Benson and Krause (1984) from temperature and a constant salinity of 38 . The computation of metabolic rates (GPP, CR, NCP) by open water mass balance of $\mathrm{O}_{2}$ is based on the Odum (1956) method: the hourly change of $\mathrm{O}_{2}$ in the mixed layer corrected for the exchange of $\mathrm{O}_{2}$ with the atmosphere during nighttime corresponds to hourly rate of $\mathrm{CR}$; the hourly change of $\mathrm{O}_{2}$ in the mixed layer corrected for the exchange of $\mathrm{O}_{2}$ with the atmosphere during daytime corresponds to hourly rate of NCP; assuming that the hourly rate of $\mathrm{CR}$ is constant through the daily cycle, hourly rate of GPP is computed as NCP + CR (where CR is a negative flux) (Supporting Information Fig. S1). GPP is integrated at daily scale by multiplying the hourly rate by the photoperiod (Hd). $\mathrm{CR}$ is integrated at daily scale by multiplying the hourly rate by 24 . Daily integrated NCP is computed as the sum of daily integrated GPP and daily integrated CR.

Since the water column at the mooring site was always vertically isothermal (mixed from surface to seafloor, Champenois and Borges 2012) computations were made using the integrated $\mathrm{O}_{2}$ content in the whole water column $(10 \mathrm{~m})$ based on the measurements at the 3 depths $(4.5,7.0$, and $9.5 \mathrm{~m})$. The data are integrated to provide the vertical integrated content of $\mathrm{O}_{2}\left(\mathrm{Q}_{\mathrm{O} 2}\right.$ in $\left.\mathrm{mmol} \mathrm{m}^{-2}\right)$ on an hourly basis. Computations were made by considering a 24-h cycle starting at sunrise of a given day. Daily integrated CR $\left(\mathrm{mmol} \mathrm{O}_{2} \mathrm{~m}^{-2}\right.$ $\mathrm{d}^{-1}$ ) was computed according to:

$$
\mathrm{CR}=24 \times\left(\sum\left(\left(\mathrm{Q}_{\mathrm{O} 2 n}\right)_{t+1}-\left(\mathrm{QO}_{2 n}\right)_{t}\right)+\sum \mathrm{FO}_{2 n}\right) / \mathrm{Hn},
$$

where $\left(\mathrm{QO}_{2 n}\right)_{t+1}-\left(\mathrm{QO}_{2 n}\right)_{t}$ is the change in $\mathrm{Q}_{\mathrm{O} 2}$ during nighttime $\left(\mathrm{QO}_{2 n}\right)$ between two hourly intervals $(t), \mathrm{FO}_{2 n}$ is the airsea $\mathrm{O}_{2}$ exchange at each $t$ during nighttime computed using the Ho et al. (2006) gas transfer parameterization as function of wind speed (where the efflux of $\mathrm{O}_{2}$ from water to atmosphere corresponds to positive $\mathrm{FO}_{2 n}$ ), and $\mathrm{Hn}$ is the nighttime duration given by:

$$
\mathrm{Hn}=24-\mathrm{Hd} .
$$

Daily integrated GPP $\left(\mathrm{mmol} \quad \mathrm{O}_{2} \quad \mathrm{~m}^{-2} \quad \mathrm{~d}^{-1}\right)$ is computed according to:

$$
\mathrm{GPP}=\sum\left(\left(\mathrm{QO}_{2 d}\right)_{t+1}-\left(\mathrm{QO}_{2 d}\right)_{t}\right)+\sum \mathrm{FO}_{2 d}-\mathrm{CR},
$$

where $\left(\mathrm{QO}_{2 d}\right)_{t}+1-\left(\mathrm{QO}_{2 d}\right)_{t}$ is the change in $\mathrm{QO}_{2}$ during daytime $\left(\mathrm{QO}_{2 d}\right)$ between two $t, \mathrm{FO}_{2 d}$ is the air-sea $\mathrm{O}_{2}$ exchange at each $t$ during daytime. $\sum \mathrm{FO}_{2 n}$ corresponded on average to $6 \% \pm 27 \%$ of $\sum\left(\left(\mathrm{Q}_{\mathrm{O} 2 n}\right)_{t+1}-\left(\mathrm{QO}_{2 n}\right)_{t}\right)$ and $\sum \mathrm{FO}_{2 d}$ corresponded on average to $8 \% \pm 20 \%$ of $\sum\left(\left(\mathrm{QO}_{2 d}\right)_{t+1}-\left(\mathrm{QO}_{2 d}\right)_{t}\right)$ showing that, at our particular productive and shallow site, the contribution of the air-sea $\mathrm{O}_{2}$ exchange to the overall $\mathrm{O}_{2}$ budget and on the calculation of metabolic rates was marginal.

For the benthic chamber incubations, GPP, NCP, and CR were computed as above for the data from the optodes, except that $\mathrm{Q}_{\mathrm{O} 2}\left(\mathrm{mmol} \mathrm{m}^{-2}\right)$ was computed from the $\mathrm{O}_{2}$ concentration $\left(\mathrm{mmol} \mathrm{m}^{-3}\right)$, the volume of the chamber $\left(\mathrm{m}^{3}\right)$ divided by the surface of the chamber $\left(\mathrm{m}^{2}\right)$, and the $\mathrm{FO}_{2}$ term was ignored. The scaling to the surface of the meadow was done by normalizing the metabolic fluxes by the number of shoots within each benthic chamber, and then using the shoot density using the average value from all measurements (425 \pm 92 shoots $\mathrm{m}^{-2}$ ).

Dissolved inorganic carbon (DIC) and the calcite and aragonite saturation levels were computed from $\mathrm{pH}$ and TA measurements using carbonic acid constants of Mehrbach et al. (1973) with Microsoft Excel version of CO2SYS. This allowed $\mathrm{pH}$ to be recomputed from temperature of measurement to in-situ temperature.

The air-sea flux of $\mathrm{CO}_{2}$ (and $\mathrm{CH}_{4}$ ) was computed from airsea concentration gradient of $\mathrm{CO}_{2}$ (and $\mathrm{CH}_{4}$ ) and the gas transfer velocity of $\mathrm{Ho}$ et al. (2006) computed from wind speed. The atmospheric $\mathrm{pCO}_{2}$ was obtained at Lampedusa island from GLOBALVIEW-CO2 (Carbon Cycle Greenhouse Gases Group of the National Oceanic and Atmospheric Administration, Earth System Research Laboratory), and converted into wet air using the water vapor algorithm of Weiss and Price (1980). The atmospheric $\mathrm{CH}_{4}$ was assumed equal to $1.8 \mathrm{ppm}$.

Statistical tests and type II linear regressions (Deming) were made with Graphpad Prism (version 7.04). Annual fluxes were derived from the average of spline cubic curves on the benthic incubation values or the monthly means of metabolic fluxes derived from optode mooring.

\section{Results and discussion}

\section{Seasonal and interannual variability of GPP, CR, and NCP}

We obtained 3275 measurements of community metabolism fluxes during a period of $12 \mathrm{yr}$ over a $P$. oceanica meadow at $10 \mathrm{~m}$ depth (Fig. 1a). GPP ranged between 0.4 and $1818 \mathrm{mmol} \mathrm{O}_{2} \mathrm{~m}^{-2} \mathrm{~d}^{-1}$ and averaged $229 \pm 180 \mathrm{mmol} \mathrm{O}_{2} \mathrm{~m}^{-2}$ $\mathrm{d}^{-1}$; CR ranged between -1370 and $-0.5 \mathrm{mmol} \mathrm{O}_{2} \mathrm{~m}^{-2} \mathrm{~d}^{-1}$ and averaged $-163 \pm 140 \mathrm{mmol} \mathrm{O}_{2} \mathrm{~m}^{-2} \mathrm{~d}^{-1}$; NCP ranged between -166 and $539 \mathrm{mmol} \mathrm{O}_{2} \mathrm{~m}^{-2} \mathrm{~d}^{-1}$ and averaged $63 \pm 64 \mathrm{mmol} \mathrm{O}_{2} \mathrm{~m}^{-2} \mathrm{~d}^{-1}$.

The variations of the daily values of the three community metabolic fluxes were dominated by strong day-to-day variability (Fig. 1a), while the monthly averaged values showed more regular seasonal variations but also interannual variations (Fig. 1b). The seasonal cycle of GPP followed the one leaf 
(a)

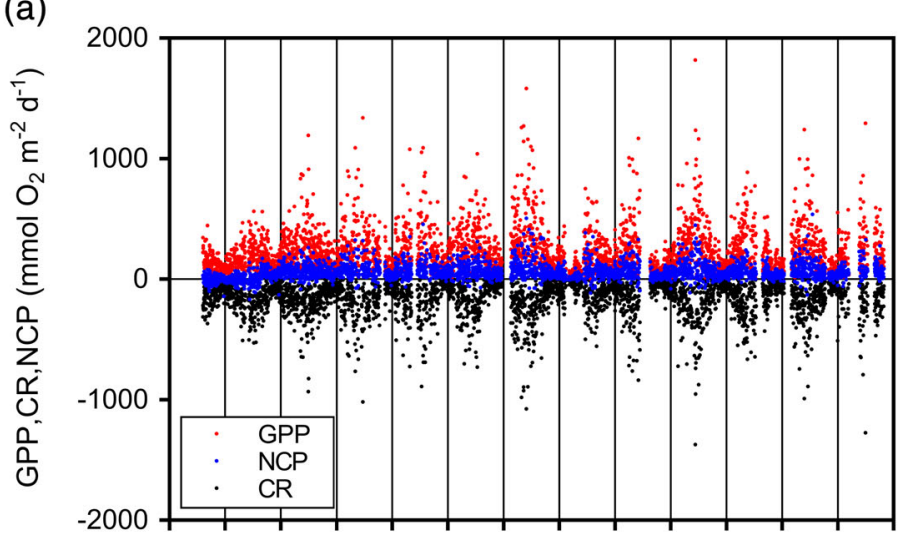

(b)

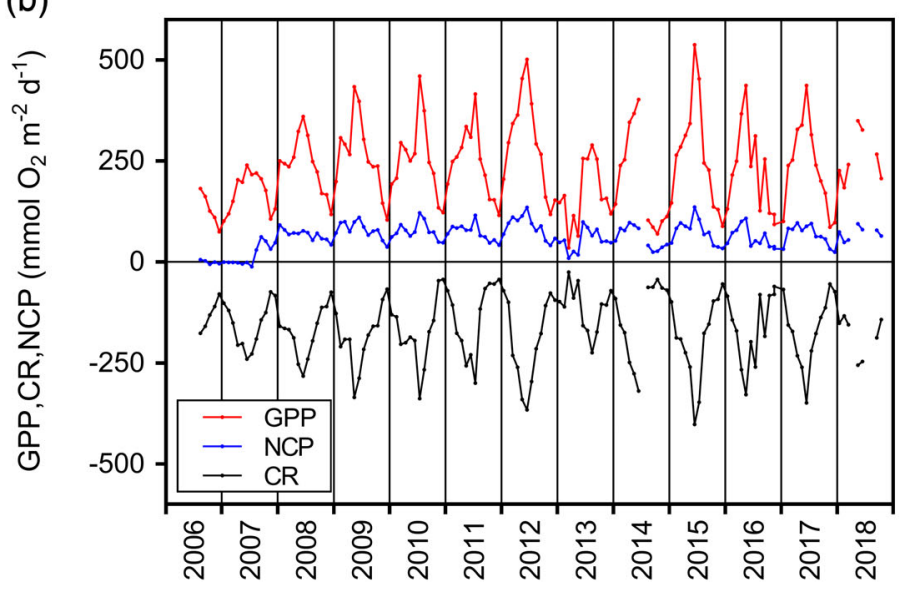

Fig. 1. Gross primary production (GPP), community respiration (CR), net community production (NCP) in $\mathrm{mmol} \mathrm{O}_{2} \mathrm{~m}^{-2} \mathrm{~d}^{-1}$ over a Posidonia oceanica meadow in the Bay of Revellata at $10 \mathrm{~m}$ bottom depth from 7 August 2006 to 29 October 2018, given as (a) daily values $(n=3275)$ and as (b) monthly averages. Data gaps correspond to periods of maintenance of optodes or data loss due to instrument malfunction. biomass with a yearly minimum in November-December and a maximum in June-July (Bay 1984). Interannual variations of GPP were driven by variable light regime (due to changes in incoming light and shading from phytoplankton) as well as water temperature, and fall- and wintertime storms (Champenois and Borges 2019). The years with the lowest GPP were 2007 and 2015, due to low fall-winter storms that did not trigger the export of litter and consequently inhibited the development of benthic sciaphile macroalgae (Champenois and Borges 2012, 2019). For other years, GPP was repeatable for the period from September to February, so interannual variations of GPP were mostly observed during the period from March to August. During this period, interannual variations of GPP were mostly due to interannual variations of incoming solar radiation and slightly modulated to other factors such as nutrient inputs and water temperature (Champenois and Borges 2019). We validated the statistical model of GPP developed from the 2006 to 2016 data-set (Champenois and Borges 2019) with the independent data point in 2017 (Supporting Information Fig. S2).

The seasonal variations of CR mirror closely the seasonal variations of GPP (Fig. 1b), as previously shown in other individual macrophyte communities (Barrón et al. 2006; Koopmans et al. 2020), as well as across various individual systems of a given community (Gattuso et al. 1998). The close coupling of GPP and CR occurred at seasonal scale (Fig. 1b) but also at daily scale, whatever the season, as shown by two time series of $10 \mathrm{~d}$ in winter and summer (Fig. 2). The CR measurements correspond to the sum of autotrophic respiration (AR) and heterotrophic respiration (HR) (Supporting Information Fig. S1). It is notoriously difficult to separate the individual contribution of AR and HR to CR (Del Giorgio and Williams 2005). AR is linked to GPP at scale of minutes to hours, while HR is linked to GPP at the scale of hours to days for bacteria and days to weeks for metazoans (Del Giorgio and (a)

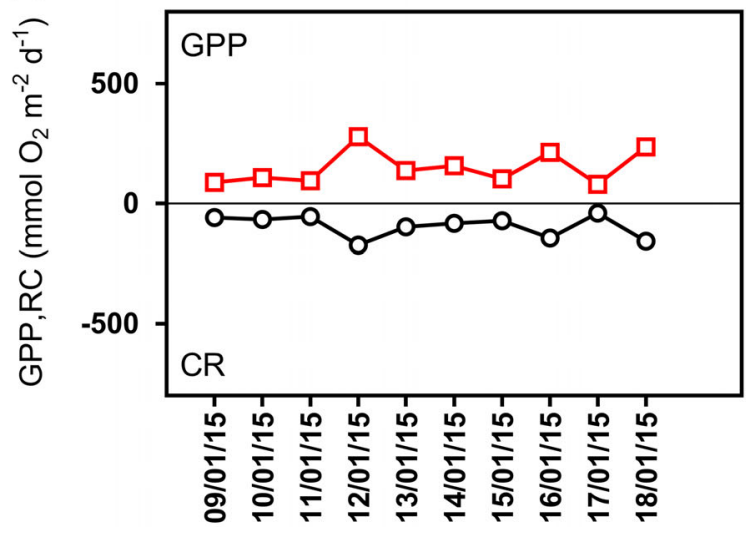

(b)

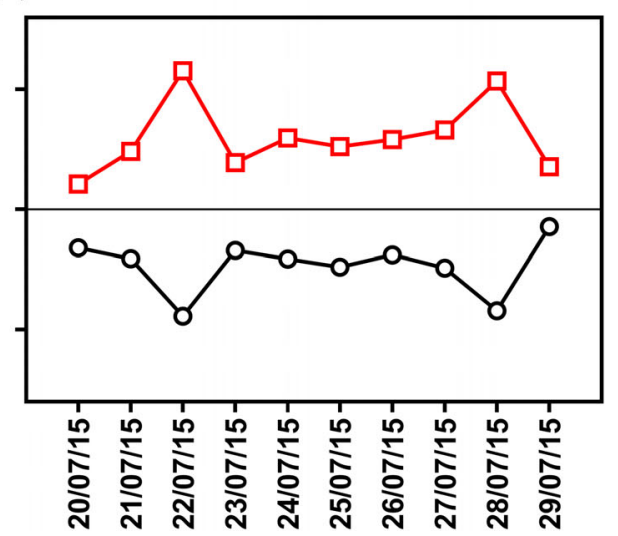

Fig. 2. Two examples of $10 \mathrm{~d}$ time series of gross primary production (GPP) and community respiration (CR) in $\mathrm{mmol} \mathrm{O}_{2} \mathrm{~m}^{-2} \mathrm{~d}^{-1}$ over a Posidonia oceanica meadow in the Bay of Revellata at $10 \mathrm{~m}$ bottom depth during winter (a) and summer (b). Note the different scales of $Y$-axis. 
Williams 2005). In seagrasses, AR corresponds on average to $57 \%$ of GPP according to Duarte and Cebrián (1996). It is then likely that the tight symmetry between CR and GPP is mainly due to a close coupling between AR and GPP. There is a tight coupling between mitochondrial respiration and photosynthesis in microalgae (Bailleul et al. 2015) and higher terrestrial plants (Noguchi and Yoshida 2008). However, Rasmusson and Björk (2014) showed for Zostera marina that mitochondrial respiration was downregulated by light. Yet, this does not necessarily exclude that AR might be enhanced during nighttime, following higher GPP linked to better light conditions.

In addition, $P$. oceanica could release substantial amounts of DOC according to Barrón and Duarte (2009). Heterotrophic bacteria can rapidly assimilate freshly produced phytoplanktonic DOC (Marañón et al. 2004; Morana et al. 2014), and if this also occurs in $P$. oceanica meadows, enhanced HR in response to DOC release associated to high GPP might also contribute to the close coupling of GPP and CR. Adams et al. (2016) investigated the mechanism responsible for the hysteresis in diurnal pattern of oxygen flux in Zostera muelleri and tested whether this was caused by HR stimulated by DOC exudation or changes in AR. They concluded that the rate of DOC exudation by seagrass was not sufficient to support a diurnal variation in HR. So, whether the observed coupling of GPP and CR is related to a specific coupling of AR or HR to GPP remains an open question.

NCP also showed distinct seasonal and inter-annual variations (Fig. 1 and Supporting Information Fig. S3). NCP was in general minimal in November-December, on average $\sim 40 \pm 15 \mathrm{mmol} \mathrm{O}_{2} \mathrm{~m}^{-2} \mathrm{~d}^{-1}$ (Fig. 3b) corresponding to the period of minimal canopy biomass (Fig. 3a). This was followed by an increase of NCP due to the growth and elongation of $P$. oceanica leaves that peaked in biomass in June with NCP averaging $\sim 83 \pm 39 \mathrm{mmol} \quad \mathrm{O}_{2} \quad \mathrm{~m}^{-2} \mathrm{~d}^{-1} \quad$ (Fig. 3a,b). In September, there was a slight increase of NCP averaged for the $12 \mathrm{yr}$ (Fig. 3a) due to the export of litter with fall storms allowing light penetration to the sediment and $P$. oceanica rhizomes and the development of benthic sciaphile macroalgae. For individual years (Supporting Information Fig. S3), the increase of NCP in September was distinctly observed in 2008, 2009, 2012, 2013, 2015, and 2016, but less marked in 2010, 2011, and 2017. The absence of storms in fall-winter 2007 and 2014 did not flush the meadow of litter, blocking the development of benthic sciaphile macroalgae, consequently, no increase of NCP was observed in September of these 2 years.

NCP was significantly positively correlated to GPP (Fig. 4a), in agreement with the general pattern in several marine ecosystem from a meta-analysis by Duarte and Agustí (1998). During periods of high production of organic matter (high GPP) there is a tendency for accumulation of organic matter that can be exported or stored (positive NCP), while during periods of low GPP there is a tendency to consume exhaustively the lower available resources driving systems toward low or
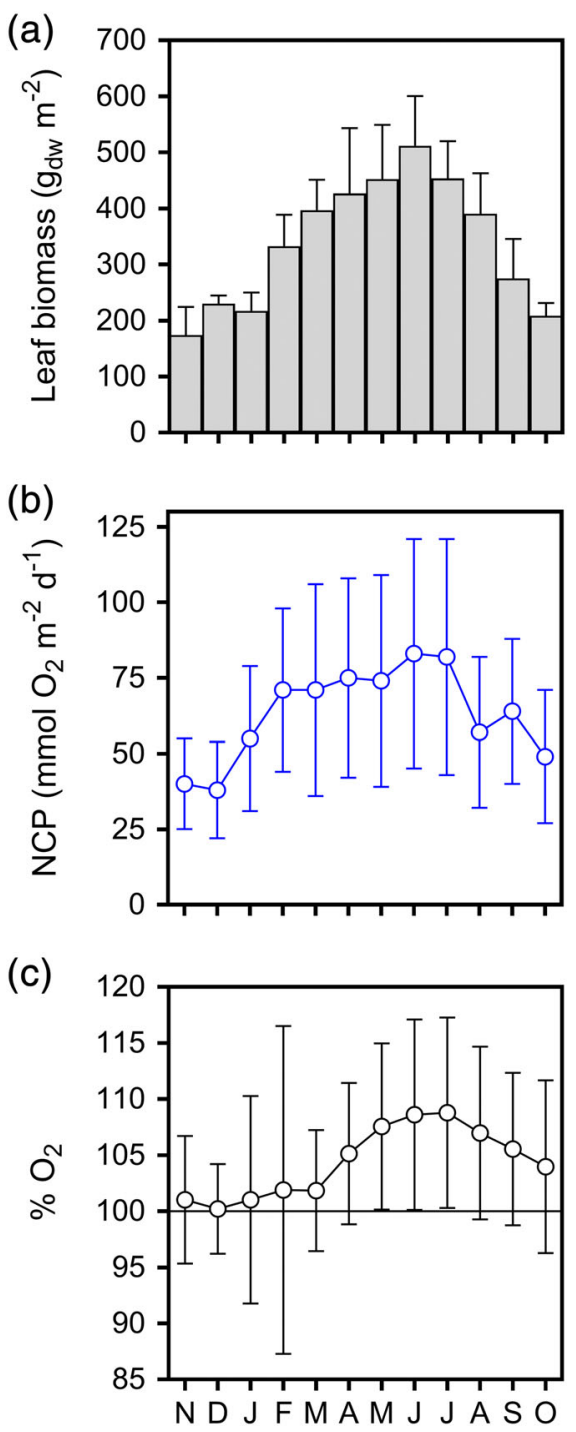

Fig. 3. Climatological monthly average over a Posidonia oceanica meadow in the Bay of Revellata at $10 \mathrm{~m}$ bottom depth of leaf biomass (1976-1977) (Bay 1984) (a), of net community production (NCP) in mmol $\mathrm{O}_{2} \mathrm{~m}^{-2} \mathrm{~d}^{-1}(\mathbf{b})$ and oxygen saturation level $\left(\% \mathrm{O}_{2}\right)$ (equilibrium with the atmosphere $=100 \%$ ) at $9.5 \mathrm{~m}$ depth (just above the top of the seagrass canopy) (c) (7 August 2006-29 October 2018). Error bars correspond to the standard deviation on the mean.

negative NCP. NCP was also significantly correlated with CR (Fig. 4b) although with more scatter (lower $r^{2}$ ). The NCP-CR correlation was probably indirect and spurious, reflecting the strong correlation between GPP and CR (Fig. 4c).

\section{Net community metabolic status}

Community metabolic data and $\% \mathrm{O}_{2}$ data show the studied $P$. oceanica meadow at $10 \mathrm{~m}$ was net autotrophic at yearly scale (Fig. 4a). The overall average of NCP during the whole 12-yr period was positive $\left(23 \pm 8 \mathrm{~mol} \mathrm{O}_{2} \mathrm{~m}^{-2} \mathrm{yr}^{-1}\right)$, and GPP $\left(83 \pm 15 \mathrm{~mol} \mathrm{O}_{2} \mathrm{~m}^{-2} \mathrm{yr}^{-1}\right)>-\mathrm{CR}\left(-60 \pm 9 \mathrm{~mol} \mathrm{O}_{2} \mathrm{~m}^{-2} \mathrm{yr}^{-1}\right)$. 
(a)

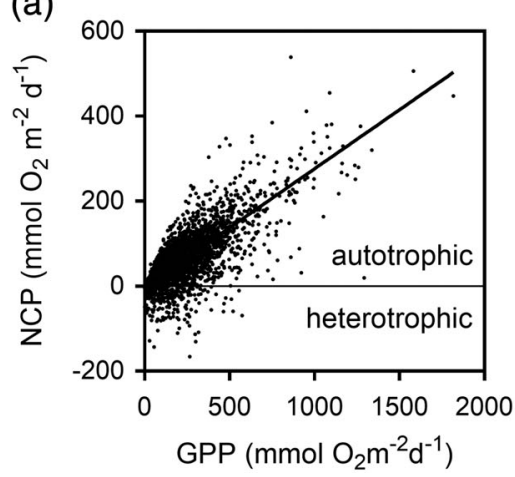

(b)

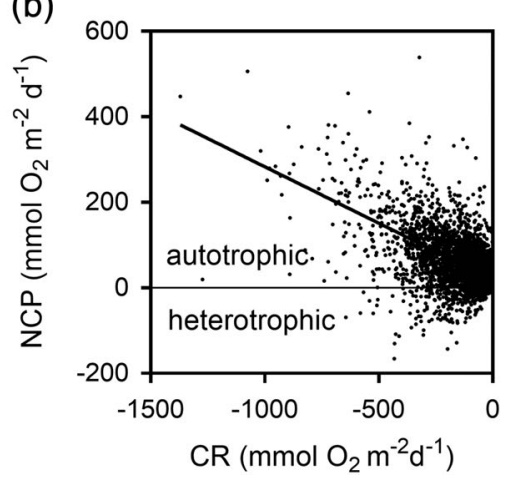

(c)

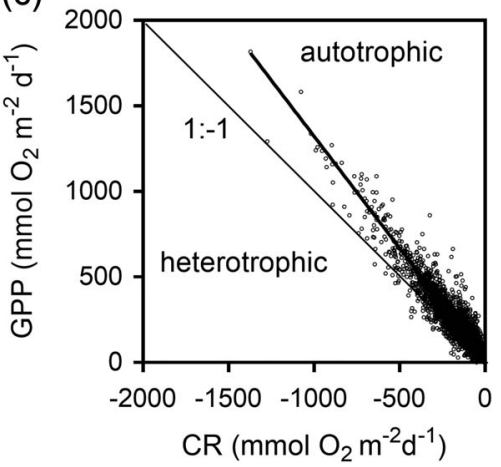

Fig. 4. Net community production (NCP) vs. gross primary production (GPP) (a), NCP vs. community respiration (CR) (b), and GPP vs. CR in mmol $\mathrm{O}_{2}$ $\mathrm{m}^{-2} \mathrm{~d}^{-1}$ (c) over a Posidonia oceanica meadow in the Bay of Revellata at $10 \mathrm{~m}$ bottom depth from 7 August 2006 to 29 October 2018 . Solid thick lines indicate linear regression: $\mathrm{NCP}=0.28( \pm 0.01) \mathrm{GPP}-1.3( \pm 1.5)\left(r^{2}=0.55, p<0.0001, n=3275\right), \mathrm{NCP}=-0.26( \pm 0.01) \mathrm{CR}+19.1( \pm 2.0)\left(r^{2}=0.24\right.$, $p<0.0001, n=3275), \mathrm{GPP}=-1.31( \pm 0.01) \mathrm{CR}+15.5( \pm 1.9)\left(r^{2}=0.89, p<0.0001, n=3275\right)$.

This was also reflected on comparison of individual GPP and CR measurements (Fig. 4c). The slope of the regression $(-1.31)$ was statistically lower than -1 (at 95\% confidence intervals -1.33 to -1.28 ) (corresponding to a balanced metabolism, $\mathrm{GPP}=\mathrm{CR})$, and for $90 \%$ of individual measurements GPP > $-\mathrm{CR}(n=2944$ vs. $n=3275)$. If data from year 2007 are excluded, because it was abnormal due the absence of fallwinter storms that off-set the normal patterns of community metabolism (Champenois and Borges 2012), then 94\% of individual measurements GPP $>-\mathrm{CR}(n=2722$ vs. $n=2895)$. In addition, $\% \mathrm{O}_{2}$ generally followed the patterns of NCP (Fig. $4 \mathrm{c}$ ) with higher values in June-July $(108.6 \% \pm 8.5 \%)$ and lowest values in November-December $(100.6 \% \pm 5.0 \%)$, and an overall average of $104.3 \% \pm 8.4 \%$. An overall oversaturation of $\mathrm{O}_{2}$ with respect to atmospheric equilibrium is only possible in a system where there is a production of $\mathrm{O}_{2}$ by GPP in excess of $\mathrm{CR}$, corresponding by definition to a net autotrophic system.

In the same site (Bay of Revellata), Velimirov et al. (2016) arrived at the opposite conclusion that the $P$. oceanica meadow was net heterotrophic based on bacterial carbon demand (BCD) derived from incubations of ${ }^{3} \mathrm{H}$-thymidine and ${ }^{14} \mathrm{C}$ leucine in both the water column and sediment, which were found to be in excess of primary production. There are several possible explanations for the opposing conclusions on net community metabolism of the present study and the one of Velimirov et al. (2016). First, the BCD was compared to $P$. oceanica primary production estimated from change of leaf biomass from Bay (1984) (combination of marking technique and harvesting technique). However, the majority of the BCD in the water column should be fueled by DOC exudation that could be substantial in $P$. oceanica meadows (Barrón and Duarte 2009), but cannot be accounted by the estimation of primary production based on change of leaf biomass. Second, the BCD data of Velimirov et al. (2016) were acquired in 1992 and 1993 and were compared to $P$. oceanica primary production estimates from different years $(1978,1981,1984,1995$,
2002, 2003), when our own measurements show that GPP and CR can be extremely variable from day-to-day, seasonally, and year to year (Fig. 1a,b). Third, the benthic BCD reported by Velimirov et al. (2016) is mostly likely overestimated due to an overestimation of the oxic sediment layer, over which the benthic BCD was vertically integrated. Velimirov et al. (2016) integrated the BCD over an oxygenated layer of $10 \mathrm{~cm}$ (the method to determine the depth of this layer was not specified by the authors). This is an extremely deep sediment oxygenated layer, usually only encountered in abyssal oceanic sediments (> $4000 \mathrm{~m}$ bottom depth), while sediment oxygenated layer has a thickness of only a few $\mathrm{mm}$ in coastal sediments (Glud et al. 1994). Measurements of $\mathrm{O}_{2}$ profiles in sediments at two sites in $P$. oceanica meadows in Mallorca show an oxic layer of $0.2-0.4 \mathrm{~cm}$ (Holmer et al. 2003). These values of oxygen penetration depth are consistent with those reported in other seagrass sediments of $0.1-0.2 \mathrm{~cm}$ (Trevathan-Tackett 2017; Brodersen et al. 2019). To our best knowledge, data of highly resolved sediment $\mathrm{O}_{2}$ microprofiles are unavailable in the $P$. oceanica meadow of the Bay of Revellata. But, we obtained, with a coarse sampling method, $\mathrm{H}_{2} \mathrm{~S}$ pore-water concentrations (Supporting Information Table S2) show that $\mathrm{H}_{2} \mathrm{~S}$ was always present at $10 \mathrm{~cm}$ depth, and in the top $1 \mathrm{~cm} \mathrm{H}_{2} \mathrm{~S}$ was nearly always present. In addition, $\mathrm{O}_{2}$ was always below detection at all sampled depths, suggesting the oxic layer should have been shallower than $1 \mathrm{~cm}$ in both bare and vegetated sediments. For an oxic layer of $10 \mathrm{~cm}$, Velimirov et al. (2016) computed a benthic BCD of $33.2 \mathrm{~mol} \mathrm{C} \mathrm{m}^{-2} \mathrm{yr}^{-1}$ at $10 \mathrm{~m}$ bottom depth that added to the pelagic $\mathrm{BCD}\left(14.5 \mathrm{~mol} \mathrm{C} \mathrm{m} \mathrm{mr}^{-1}\right)$, gave a total $\mathrm{BCD}$ of $47.7 \mathrm{~mol} \mathrm{C} \mathrm{m} \mathrm{m}^{-2} \mathrm{yr}^{-1}$. This value of BCD was well in excess of $P$. oceanica primary production at $10 \mathrm{~m}$ bottom depth of $20 \pm 4 \mathrm{~mol} \mathrm{C} \mathrm{m}{ }^{-2} \mathrm{yr}^{-1}$ reported by Velimirov et al. (2016). Reintegrating benthic BCD with a shallower but still probably overestimated value of sediment oxic layer of $0.5 \mathrm{~cm}$, would yield a total (water column and sediment) BCD of $16.2 \mathrm{~mol} \mathrm{C}$ 
$\mathrm{m}^{-2} \mathrm{yr}^{-1}$. Such reevaluated estimate of BCD would be lower than the estimate of $P$. oceanica primary production given by Velimirov et al. (2016) $\left(20 \pm 4 \mathrm{~mol} \mathrm{C} \mathrm{m}{ }^{-2} \mathrm{yr}^{-1}\right.$ at $10 \mathrm{~m}$ bottom depth), and also than our own estimate of net primary production (NPP) of $37 \pm 6 \mathrm{~mol} \mathrm{C} \mathrm{m}^{-2} \mathrm{yr}^{-1}$ (also at $10 \mathrm{~m}$ bottom depth), implying a net autotrophic status. Our own estimate of NPP was computed as NPP = GPP $-\mathrm{AR}$, assuming AR corresponds to 57\% of GPP (Duarte and Cebrián 1996), and using a photosynthetic quotient (PQ) of 1 (see below). Note that anaerobic benthic organic matter degradation (dominated by sulfate reduction) was $\sim 1 \mathrm{~mol} \mathrm{C} \mathrm{m} \mathrm{yr}^{-1}$ in a pristine meadow site in Mallorca (Holmer et al. 2003).

The metabolic balance of $P$. oceanica meadows in the Bay of Revellata was also found to be positive (net autotrophic) based on $\mathrm{O}_{2}$ benthic incubations in the 1980s (Frankignoulle and Bouquegneau 1987), as well as in two other P. oceanica meadows in the Mediterranean (Magalluf Bay and Sounion) (Barrón et al. 2006; Apostolaki et al. 2010). Net autotrophy is also in agreement with the fact these communities store (Mateo et al. 1997) and export to adjacent communities very large amounts of organic matter (Cebrián and Duarte 1998), and are net producers of $\mathrm{O}_{2}$ in excess of atmospheric equilibrium (see above).

\section{Comparison of community metabolic rates based on oxygen and inorganic carbon changes}

The overall carbon budget in seagrass meadows depends on the balance of processes of production, destruction, storage, and export of organic matter and of $\mathrm{CaCO}_{3}$, respectively, the "organic carbon metabolism" and the "inorganic carbon metabolism" (Barrón et al. 2006; Yates and Halley 2006; Howard et al. 2018; Van Dam et al. 2019). We carried out measurements of DIC and TA in benthic chambers that allow computing the net daily fluxes of these two quantities ( $F_{\mathrm{DIC}}$ and $F_{\mathrm{TA}}$, respectively). The regression of $F_{\mathrm{DIC}}$ as function of $F_{\mathrm{TA}}$ (Supporting Information Fig. S4) gave a slope of $0.48 \pm 0.17$ which is consistent with the one expected if the relative variation of TA with regards to DIC is driven by $\mathrm{CaCO}_{3}$ precipitation or DIS (Smith and Key 1975), according to equation:

$$
2 \mathrm{HCO}_{3}^{-}+\mathrm{Ca}^{2+} \leftrightarrow \mathrm{CaCO}_{3}+\mathrm{CO}_{2}+\mathrm{H}_{2} \mathrm{O},
$$

whereby for each mole of $\mathrm{CaCO}_{3}$ precipitated (or dissolved), the decrease (or increase) of DIC is two times lower than the decrease (or increase) of TA.

The flux of DIC can then be corrected to only give the flux of DIC related to organic carbon metabolism (DIC*) by removing the term related to CAL/DIS (Smith and Key 1975), according to:

$$
\mathrm{DIC} *=\mathrm{DIC}-\mathrm{TA} / 2 .
$$

The consistency of this approach can be tested by comparing NCP derived from $\mathrm{O}_{2}$ incubations (abbreviated as previously-
$\mathrm{NCP})$ with NCP derived from uncorrected DIC $\left(\mathrm{NCP}_{\mathrm{DIC}}\right)$ and

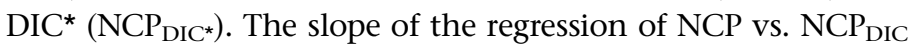
of $-0.51 \pm 0.18$ (at $95 \%$ confidence intervals -0.96 to -0.12 ) was lower than the slope of the regression of NCP vs. $\mathrm{NCP}_{\mathrm{DIC}^{*}}$ of $-0.71 \pm 0.17$ (at $95 \%$ confidence intervals -1.08 to -0.34 ) (Supporting Information Fig. S5). This confirms that DIC dynamics were affected by CAL/DIS and that $\mathrm{DIC}^{*}$ gives a better estimate of the changes of DIC related to organic production/destruction processes.

Yet, the direct comparison community metabolic rates derived from $\mathrm{O}_{2}$ changes and $\mathrm{DIC}^{*}$ changes requires the conversion of rates measured by $\mathrm{O}_{2}$ changes in rates expressed in carbon. The PQ corresponds to the molar ratio of the release of $\mathrm{O}_{2}$ to the consumption of DIC during photosynthesis while the respiratory quotient $(\mathrm{RQ})$ corresponds to the molar ratio of the release of DIC to the consumption of $\mathrm{O}_{2}$ during organic matter mineralization. The values of $P Q$ and RQ depend on the relative abundance of carbon, nitrogen and phosphorous of the average composition of organic matter that for $P$. oceanica leaves is given, according to Atkinson and Smith (1983), by the following equation:

$$
\begin{aligned}
& 956 \mathrm{CO}_{2}+995 \mathrm{H}_{2} \mathrm{O}+39 \mathrm{HNO}_{3}+\mathrm{H}_{3} \mathrm{PO}_{4} \\
& \leftrightarrow\left(\mathrm{CH}_{2} \mathrm{O}\right)_{956}(\mathrm{NH} 3)_{39} \mathrm{H}_{3} \mathrm{PO}_{4}+1034 \mathrm{O}_{2}
\end{aligned}
$$

which allows to compute a theoretical value of 1.08 for PQ and of 0.92 for RQ for production and respiration of P. oceanica organic matter.

Nighttime CR from DIC* change $\left(\mathrm{CR}_{\mathrm{DIC}^{*}(\text { night })}\right)$ was computed from $F_{\text {DIC }}$ during nighttime $\left(F_{\text {DIC (night) }}\right)$ and $F_{\mathrm{TA}}$ during nighttime $\left(F_{\mathrm{TA}(\text { night })}\right)$ according to:

$$
\mathrm{CR}_{\mathrm{DIC} *(\text { night })}=F_{\mathrm{DIC}(\text { night })}-0.5 \times F_{\mathrm{TA}(\text { night })} .
$$

$\mathrm{CR}_{\text {DIC }^{*} \text { (night) }}$ was well correlated to CR derived from $\mathrm{O}_{2}$ incubations (abbreviated as previously- $\mathrm{CR}$ ) and the resulting slope was $-0.97 \pm 0.18$ not statistically different from -1 (at $95 \%$ confidence intervals -1.35 to -0.59 ) and close to the theoretical RQ of 0.92. (Supporting Information Fig. S6). Assuming that $\mathrm{CR}_{\mathrm{DIC}^{\star} \text { (night) }}$ is the same during the night and during the day, it is used to derive the GPP based on changes of DIC* $\left(\mathrm{GPP}_{\mathrm{DIC}^{\star}}\right)$ according to:

$$
\mathrm{GPP}_{\mathrm{DIC} *}=\mathrm{NCP}_{\mathrm{DIC} *}-\mathrm{CR}_{\mathrm{DIC} *}
$$

$\mathrm{GPP}_{\mathrm{DIC}^{*}}$ was well correlated to GPP derived from $\mathrm{O}_{2}$ incubations (abbreviated as previously-GPP) and the resulting slope was $-1.03 \pm 0.21$ not statistically different from -1 (at 95\% confidence intervals -1.48 to -0.58 ), was identical to the experimentally determined $\mathrm{RQ}$, and close to the theoretical $P Q$ of 1.08. (Supporting Information Fig. S6). Hereafter, we will consider $\mathrm{PQ}=\mathrm{RQ}=1$.

The net daily $F_{\mathrm{TA}}$ (hereafter $F_{\mathrm{TA}}$ ) was almost always positive (from the sediment to the water column) (Fig. 5a). This 
implies there was a net DIS in the sediments that needs to be compensated by an input of allochthonous $\mathrm{CaCO}_{3}$ particles (from outside of the meadow). For the August 2006-2009 sampling period, the net DIS averaged $6.8 \pm 4.9 \mathrm{~mol} \mathrm{CaCO}_{3}$ $\mathrm{m}^{-2} \mathrm{yr}^{-1}$ which is close to the $\mathrm{CaCO}_{3}$ sedimentation from the
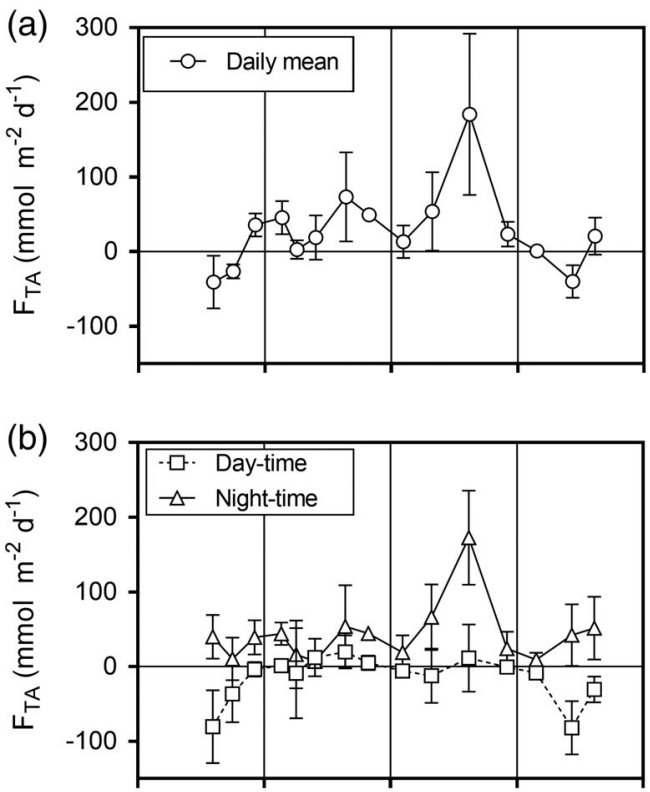

(c)

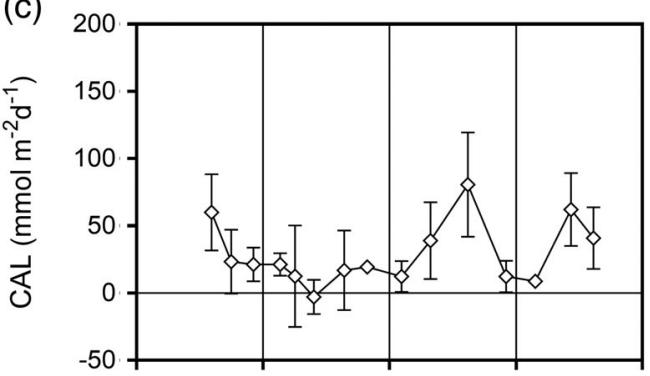

(d)

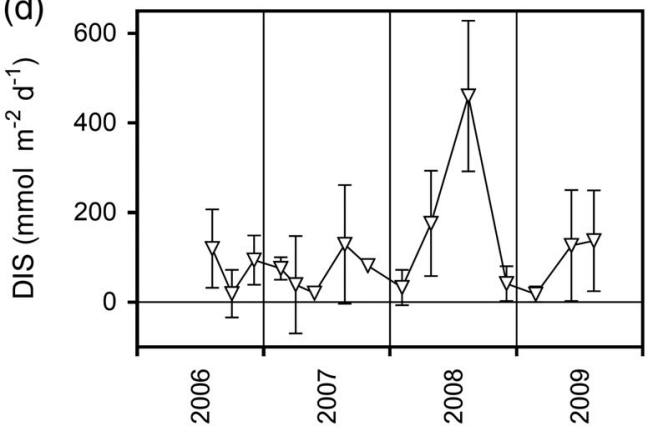

Fig. 5. Total alkanity $(T A)$ fluxes $\left(F_{T A}\right)$ from benthic chamber incubations during $24 \mathrm{~h}$, net daily (a), and during daytime (dawn to dusk) or nighttime (dusk to dawn) (b), and calcification (CAL) (c) and $\mathrm{CaCO}_{3}$ dissolution (DIS) in mmol m $\mathrm{m}^{-2} \mathrm{~d}^{-1}$ (d) over a Posidonia oceanica meadow in the Bay of Revellata at $10 \mathrm{~m}$ bottom depth from 6 August 2006 to 12 August $2009(n=15)$. Error bars correspond to standard deviation of fluxes computed from triplicate benthic chamber incubations. water column to the meadow of $7.2 \mathrm{~mol} \mathrm{CaCO}_{3} \mathrm{~m}^{-2} \mathrm{yr}^{-1}$ reported by Dauby et al. (1995) from sediment trap deployments over the $P$. oceanica meadow in the Bay of Revellata.

The $F_{\mathrm{TA}}$ was always positive during nighttime $\left(F_{\mathrm{TA}(\text { night })}\right)$ and generally close to 0 (or sometimes negative) during daytime $\left(F_{\mathrm{TA}(\mathrm{day})}\right)$ (Fig. $\left.5 \mathrm{~b}\right)$. DIS could not have occurred in the water column because the calcite and aragonite saturation levels were above 5.5 and 3.5 , respectively. We assume DIS only occurred in sediments and was independent from night and day cycles (constant whatever the period of the day). We also assume that CAL was only related to epiphytic or benthic algae, mostly related to coralline algae (Mazzella et al. 1989; Jacquemart and Demoulin 2006). We further assumed that CAL is linked to coralline algae photosynthesis (Borowitzka and Larkum 1981), and only occurred during daytime. Based on the above assumptions, we conclude that, during daytime, CAL compensated DIS, leading to $F_{\mathrm{TA}} \leq 0$ (Fig. $5 \mathrm{~b}$ ), allowing to compute daily integrated rates of DIS and CAL, according to:

$$
\mathrm{DIS}=\left(F_{\mathrm{TA}(\text { night })} / \mathrm{Hn}\right) \times 24,
$$

where Hn is the number of hours during the night.

$$
\mathrm{CAL}=-0.5 \times\left(F_{\mathrm{TA}(\text { day })}-\left(F_{\mathrm{TA}(\text { night })} / \mathrm{Hn}\right) \times \mathrm{Hd}\right),
$$

where $\mathrm{Hd}$ is the photoperiod in $\mathrm{h}$.

CAL followed a seasonal cycle and was highest in summer 2006,2008 , and 2009, but not 2007, possibly due the fact this was an exceptional year, as explained above (Fig. 5c). CAL was positively related to GPP (Supporting Information Fig. S7). This confirms our above assumption that CAL is linked to

Table 1. Net annual gross primary production (GPP), community respiration (CR), net community production (NCP), calcification (CAL), $\mathrm{CaCO}_{3}$ dissolution (DIS) and resulting $\mathrm{CO}_{2}$ fluxes in a Posidonia oceanica meadow in the Bay of Revellata at $10 \mathrm{~m}$ bottom depth. Net DIS was computed from CAL-DIS, and compared well with a different estimate based on the daily net change of total alkalinity during the incubations of $6.8 \pm 4.9 \mathrm{~mol} \mathrm{CaCO}_{3}$ $\mathrm{m}^{-2} \mathrm{yr}^{-1}$.

\begin{tabular}{ll}
\hline Organic metabolism $\left(\mathrm{mol} \mathrm{O}_{2} \mathrm{~m}^{-2} \mathrm{yr}^{-1}\right)$ & \\
GPP & $83.3 \pm 16.0$ \\
$\mathrm{CR}$ & $-60.1 \pm 9.0$ \\
$\mathrm{NCP}$ & $23.2 \pm 8.2$ \\
Inorganic metabolism $\left(\mathrm{mol} \mathrm{CaCO} \mathrm{m}^{-2} \mathrm{yr}^{-1}\right)$ & \\
$\mathrm{CAL}$ & $10.8 \pm 4.0$ \\
DIS & $-21.4 \pm 8.0$ \\
$\mathrm{Net}$ DIS & $-10.6 \pm 8.9$ \\
$\mathrm{CO}_{2}$ fluxes $\left(\mathrm{mol} \mathrm{CO}_{2} \mathrm{~m}^{-2} \mathrm{yr}^{-1}\right)$ & \\
$\mathrm{CO}_{2}$ uptake from NCP & -23 \\
$\mathrm{CO}_{2}$ update from net DIS & -6 \\
$\mathrm{Net}^{\mathrm{CO}_{2} \text { uptake }}$ & -30 \\
\hline
\end{tabular}


photosynthesis due to coralline algae (Borowitzka and Larkum 1981). While GPP represents the whole community, epiphyte and $P$. oceanica leaf GPP can be assumed to covary as the extension of $P$. oceanica leaves will provide extra surface for the development of epiphytes. The average CAL for the August 2006-2009 sampling period was $10.8 \pm 3.8 \mathrm{~mol} \mathrm{CaCO}_{3} \mathrm{~m}^{-2} \mathrm{yr}^{-1}$.

DIS also followed a seasonal cycle and was highest in summer (Fig. 5d). DIS in P. oceanica meadows is probably coupled (at least partly) to the acidification due to $\mathrm{CO}_{2}$ from benthic aerobic respiration and to oxidation by $\mathrm{O}_{2}$ of $\mathrm{H}_{2} \mathrm{~S}$, as discussed in Barrón et al. (2006) and in agreement with the ratio of DIC to TA in pore water in the Bay of Revellata (Moulin et al. 1985). Benthic respiration most probably increases in summer due to temperature increase, to translocation of oxygen to sediments (Borum et al. 2006), and to supply of labile organic matter to the sediments that should track leaf GPP. Indeed, DIS was found to be related to both CR and water temperature $\left(T\right.$ in $\left.^{\circ} \mathrm{C}\right)$, according to:

$\mathrm{DIS}=-133.3+7.89 T-0.612 \mathrm{CR}\left(F=6.169>Q_{F(0.95,2.12)} 3.89, r^{2}=0.71\right)$

with DIS in $\mathrm{mmol} \mathrm{m} \mathrm{m}^{-2} \mathrm{~d}^{-1}$ and CR in $\mathrm{mmol} \mathrm{m} \mathrm{m}^{-2} \mathrm{~d}^{-1}$.

Although CR combines both sediment and water column respiration, it is plausible that benthic respiration tracks CR, at least at seasonal scale.

\section{Organic and inorganic carbon mass balance}

Organic metabolism was greater than inorganic metabolism in the studied $P$. oceanica meadow at $10 \mathrm{~m}$ bottom depth

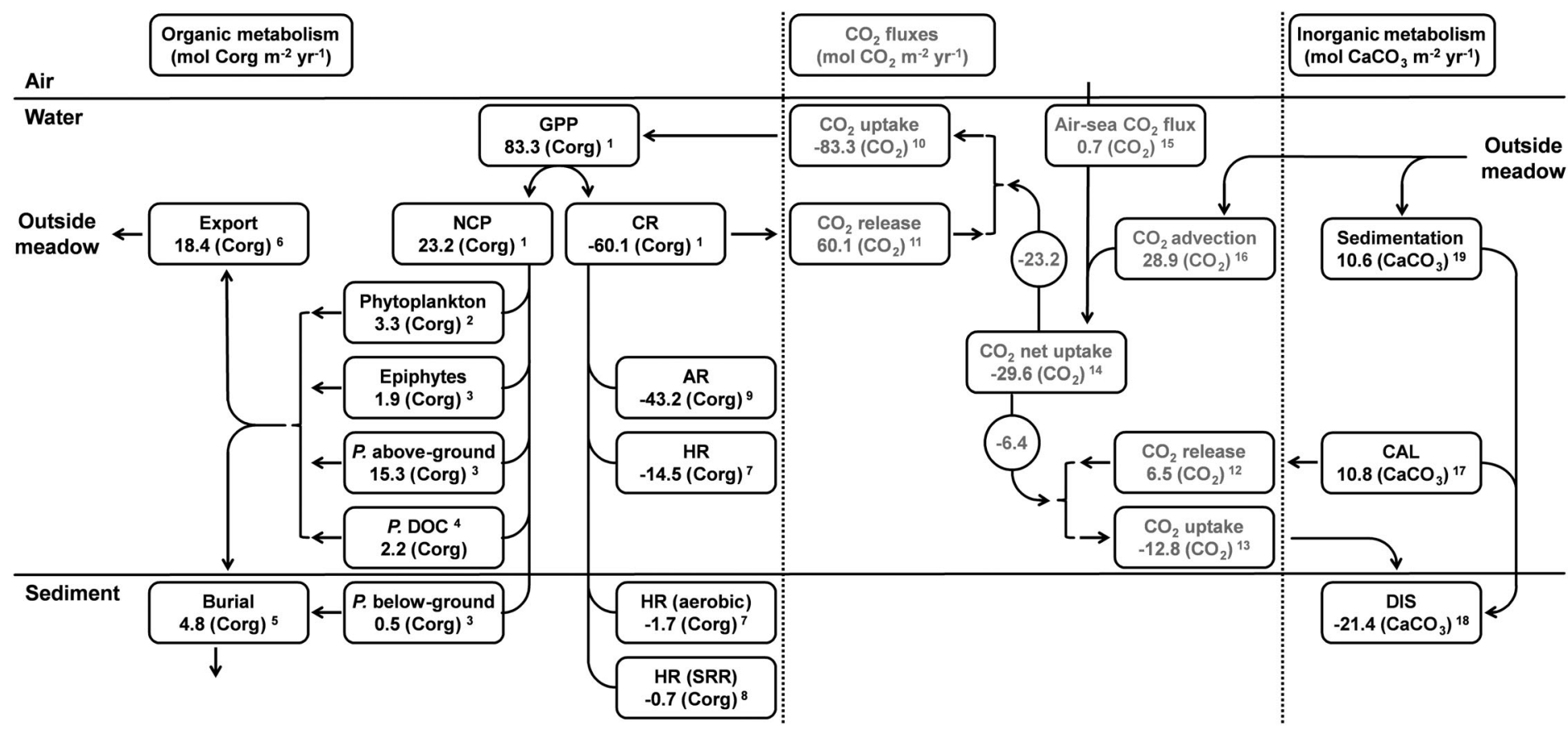

Fig. 6. Budget of fluxes of organic carbon (Corg) (mol Corg m $\left.\mathrm{m}^{-2} \mathrm{yr}^{-1}\right)$, particulate inorganic carbon $\left(\mathrm{mol} \mathrm{CaCO}_{3} \mathrm{~m}^{-2} \mathrm{yr}^{-1}\right)$, and $\mathrm{CO}_{2}\left(\mathrm{~mol} \mathrm{CO}_{2}\right.$ $\mathrm{m}^{-2} \mathrm{yr}^{-1}$ ) in a Posidonia oceanica seagrass meadow at $10 \mathrm{~m}$ depth, based on measurements from this study in the Bay of Revellata and literature data at the same site or from other $P$. oceanica meadows. ${ }^{1}$ Gross primary production (GPP), community respiration (CR), net community production (NCP) based mass balance of $\mathrm{O}_{2}$ measured with optodes on a mooring (12-yr average, this study); ${ }^{2}$ Phytoplankton primary production (phytoplankton) based on ${ }^{14} \mathrm{C}$ incubations reported by Dauby (1985) in the Bay of Revellata; ${ }^{3}$ Primary production based on biomass change of $P$. oceanica leaves $(P$. above-ground), of $P$. oceanica rhizomes and roots ( $P$. below-ground), and epiphytes reported by Bay (1984) in the Bay of Revellata; ${ }^{4}$ Dissolved organic carbon (DOC) exudation by $P$. oceanica leaves $\left(P\right.$. DOC) computed as NCP - phytoplankton - epiphytes $-P$. above-ground $-P$. below-ground; ${ }^{5}$ Sedimentary organic carbon burial rates (burial) based on radiocarbon dating and carbon content from sediment cores in seven $P$. oceanica meadows (Spain and Italy) by Mateo et al. (1997); ${ }^{6}$ Export of organic carbon to adjacent systems (Export) computed as NCP - burial; ${ }^{7}$ Bacterial heterotrophic respiration (HR) based on ${ }^{3} \mathrm{H}$ thymidine et ${ }^{14} \mathrm{C}$-leucine incubations from Velimirov et al. (2016) in the Bay of Revellata, but the benthic HR (aerobic) was reintegrated vertically over $0.5 \mathrm{~cm} ;{ }^{8}$ Sulfate reduction rate (SRR) based on ${ }^{35} \mathrm{~S}$-sulfate core incubations reported in two pristine $P$. oceanica meadows in Spain by Holmer et al. (2003) and Gacia et al. (2012); ${ }^{9}$ Autotrophic respiration (AR) computed as -CR + AR + HR + HR (aerobic) + HR (SRR); ${ }^{10}$ uptake of CO 2 by GPP computed as -GPP; ${ }^{11}$ Release of $\mathrm{CO}_{2}$ by CR computed as $-\mathrm{CR} ;{ }^{12}$ Release of $\mathrm{CO}_{2}$ by calcification (CAL) computed as $0.6 \times \mathrm{CAL}$ (Frankignoulle et al. 1994); ${ }^{13} \mathrm{Uptake}$ of $\mathrm{CO}_{2}$ by benthic $\mathrm{CaCO}_{3}$ dissolution (DIS) computed as $0.6 \times$ DIS (Frankignoulle et al. 1994); ${ }^{14}$ Net community $\mathrm{CO}_{2}$ uptake $\left(\mathrm{CO}_{2}\right.$ net uptake) computed as $-\mathrm{GPP}-\mathrm{CR}+0.6 \times \mathrm{CAL}-0.6 \times \mathrm{DIS} ;{ }^{15} \mathrm{Air}$-sea $\mathrm{CO}_{2}$ flux estimated from the measurements of the partial pressure of $\mathrm{CO}_{2}$ in the Bay of Revellata (this study); ${ }^{16}$ Inputs of $\mathrm{CO}_{2}$ by water masses circulating over the $P$. oceanica meadow computed as $-\mathrm{CO}_{2}$ net uptake - air-sea $\mathrm{CO}_{2}$ flux; ${ }^{17} \mathrm{CAL}$ derived from total alkalinity (TA) changes during benthic incubations over vegetated sediments in the Bay of Revellata (this study); ${ }^{18} \mathrm{DIS}$ derived from TA changes during benthic incubations over vegetated sediments in the Bay of Revellata (this study); ${ }^{19}$ Sedimentation of $\mathrm{CaCO}_{3}$ from the water column to the P. oceanica meadow (Sedimentation) computed as -DIS - CAL. 
(Table 1). The CAL : GPP ratio was 0.12 on average in the studied $P$. oceanica meadow which is lower than the CAL : GPP ratio reported for coralline algae of $\sim 0.7$ (El Haikali et al. 2004) and $\sim 0.5$ (Martin et al. 2013). The CAL : NPP ratio in the studied $P$. oceanica meadow was on average 0.29 which was also lower than global average estimated by van der Heijden and Kamenos (2015) for coralline algae of 1.6. The CAL : GPP and CAL : NPP were both about five times lower in the studied $P$. oceanica meadow than for the same ratios reported in the literature for coralline algae. This is in agreement with the fact that primary production is sustained by both $P$. oceanica itself and epiphyte algae, while CAL is only sustained by coralline algae. Nevertheless, the CAL : GPP of 0.12 in the studied P. oceanica meadow at $10 \mathrm{~m}$ depth is quite high, and only 2-3 times lower to the one reported in coral reefs of 0.2-0.3 (Langdon et al. 2000).

We separated carbon fluxes into different components using our own measurements and values from other studies in the Bay of Revellata or in other P. oceanica meadows (Fig. 6). AR represented $72 \%$ of CR which indicates that the close coupling of CR and GPP (Fig. 1b) seemed to be mainly related to a coupling of AR and GPP (see above). AR represented 52\% of GPP, in agreement with the value $57 \% \pm 6 \%$ reported for seagrasses by Duarte and Cebrián (1996). Sulfate-reduction rates represented about $29 \%$ of total sedimentary HR, within the range (23-43\%) typical for seagrass sediments (Holmer et al. 1999). Phytoplankton only contributed to $14 \%$ of total NCP, showing the overwhelming dominance of the contribution to NCP from the benthic compartment, itself largely dominated by $P$. oceanica, as epiphytes only contributed to $8 \%$ of total NCP. The DOC exudation rate we computed (2.2 $\mathrm{mol} \mathrm{m}^{-2} \mathrm{yr}^{-1}$ ) was comparable to the value based on direct DOC measurements reported by Barrón and Duarte (2009) of $4.4 \pm 0.9 \mathrm{~mol} \mathrm{~m}^{-2} \mathrm{yr}^{-1}$. Barrón and Duarte (2009) concluded that DOC exudation corresponded to $72 \%$ of NCP, although their NCP value of $6.1 \mathrm{~mol} \mathrm{~m}^{-2} \mathrm{yr}^{-1}$ was particularly low, almost four times lower than our own NCP estimate. Our own estimate of DOC exudation corresponded to $\sim 10 \%$ of NCP. The DOC exudation we estimated and that was measured by Barrón and Duarte (2009) corresponds to the net flux of DOC (that escapes microbial consumption of DOC). Assuming that the majority of pelagic HR is fueled by DOC exudation, than gross DOC exudation (16.7 $\mathrm{mol} \mathrm{m}^{-2} \mathrm{yr}^{-1}$ ) corresponds to $20 \%$ of GPP, a value typical of marine phytoplankton (Baines and Pace 1991). The majority of NCP was exported out of the meadow $(\sim 79 \%)$ and a small fraction buried in sediments $(\sim 21 \%)$. Note that exported organic matter can be further buried in adjacent coastal sediments, and even in deep-sea sediments (Duarte and KrauseJensen 2017). The positive NCP and the net DIS both drove a sink of $\mathrm{CO}_{2}$. For each mole of $\mathrm{CaCO}_{3}$ dissolved, $\mathrm{CO}_{2}$ decreases by about $0.6 \mathrm{~mol}$ because $\mathrm{CO}_{2}$ is in equilibrium with $\mathrm{HCO}_{3}^{-}$in seawater (Frankignoulle et al. 1994). The net balance of $\mathrm{CO}_{2}$ in the $P$. oceanica meadow was $-29.6 \mathrm{~mol} \mathrm{~m}^{-2} \mathrm{yr}^{-1}$ with DIS
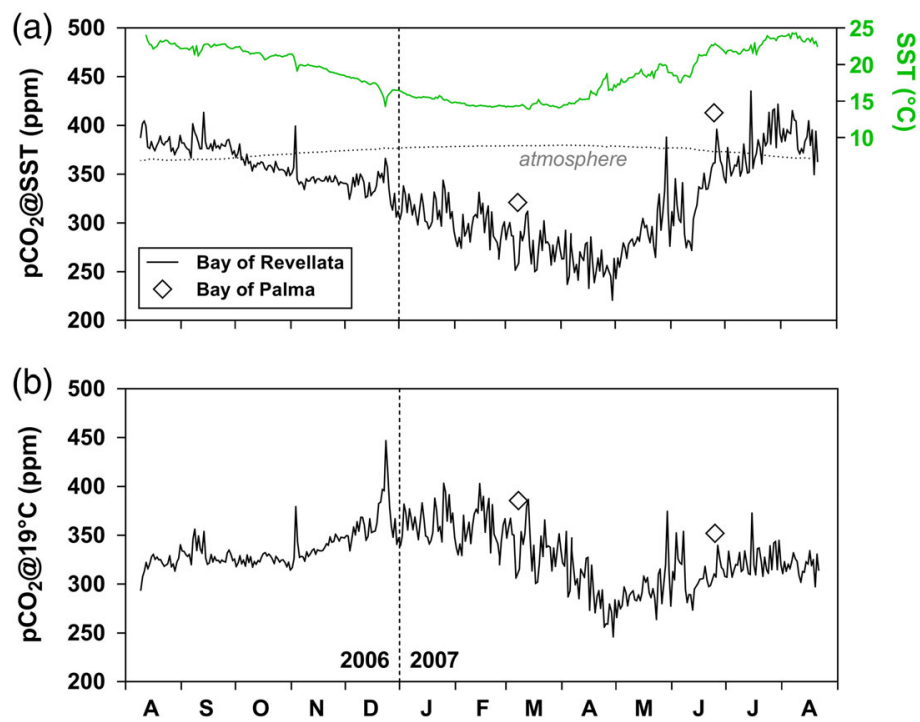

Fig. 7. Seawater partial pressure of $\mathrm{CO}_{2}\left(\mathrm{pCO}_{2}, \mathrm{ppm}\right)$ at sea surface temperature (SST in $\left.{ }^{\circ} \mathrm{C}\right)\left(\mathrm{pCO}_{2} @ \mathrm{SST}\right)(\mathbf{a})$ and normalized to constant temperature of $19^{\circ} \mathrm{C}\left(\mathrm{pCO}_{2} @ 19^{\circ} \mathrm{C}\right.$, Takahashi et al. 2002) (b) in surface water (2 $\mathrm{m}$ depth) over a Posidonia oceanica meadow in the Bay of Revellata at $10 \mathrm{~m}$ bottom depth from 9 August 2006 to 20 August 2007. Diamonds indicate $\mathrm{pCO}_{2}$ in surface water data obtained in March 2002 and June 2002 over a P. oceanica meadow in the Bay of Palma (Gazeau et al. 2005). Dotted line indicates the atmospheric $\mathrm{pCO}_{2}$.

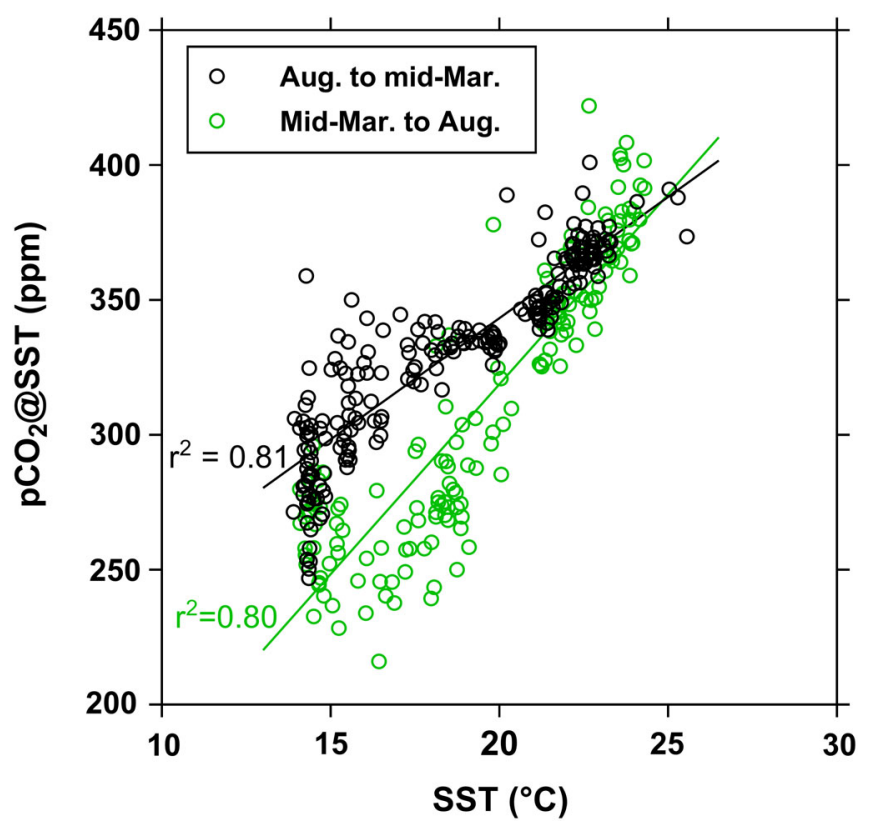

Fig. 8. Seawater partial pressure of $\mathrm{CO}_{2}\left(\mathrm{pCO}_{2}, \mathrm{ppm}\right)$ at sea surface temperature $\left(\mathrm{SST}\right.$ in $\left.{ }^{\circ} \mathrm{C}\right)\left(\mathrm{pCO}_{2} @ \mathrm{SST}\right)$ vs. SST in surface water $(2 \mathrm{~m}$ depth) over a Posidonia oceanica meadow in the Bay of Revellata at $10 \mathrm{~m}$ bottom depth from 9 August 2006 to 20 August 2007. Data were separated in two groups before and after the annual SST minimum, from August 2006 mid-March 2007 and from mid-March 2007 to August 2007. Solid lines indicate the linear regressions. 

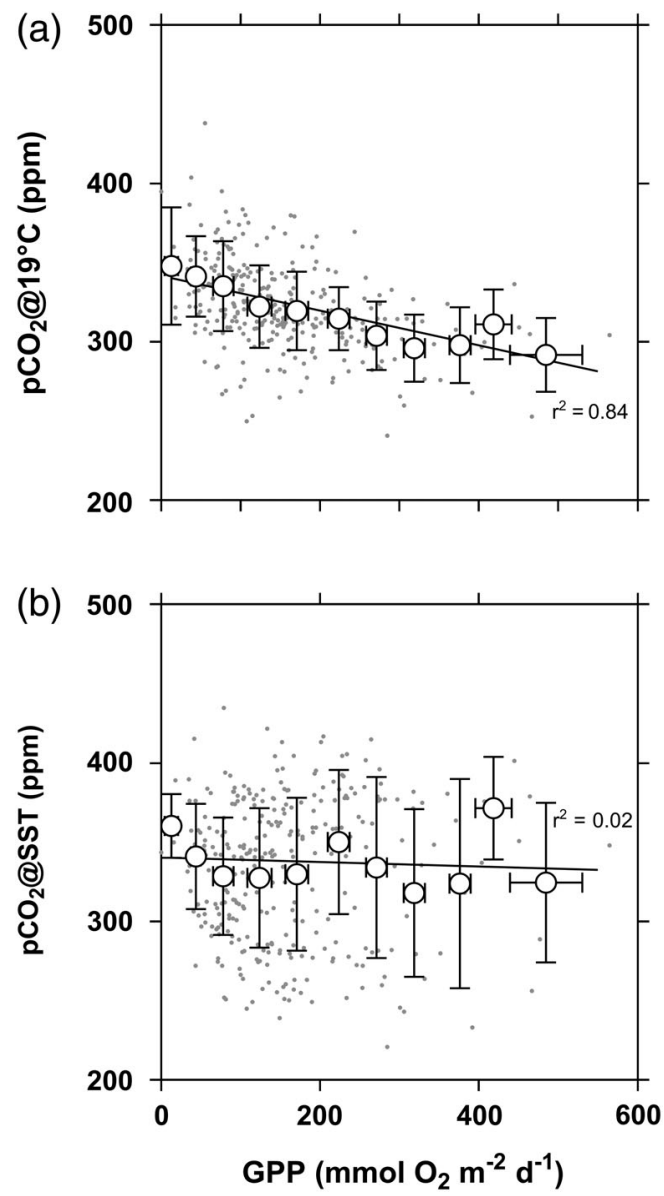

Fig. 9. Seawater partial pressure of $\mathrm{CO}_{2}\left(\mathrm{pCO}_{2}, \mathrm{ppm}\right)$ normalized to constant temperature of $19^{\circ} \mathrm{C}\left(\mathrm{pCO}_{2} @ 19^{\circ} \mathrm{C}\right.$, Takahashi et al. 2002) (a) and at sea surface temperature $\left(\mathrm{SST}\right.$ in $\left.{ }^{\circ} \mathrm{C}\right)\left(\mathrm{pCO}_{2} @ \mathrm{SST}\right)(\mathbf{b})$ in surface water $(2 \mathrm{~m}$ depth) vs. gross primary production (GPP, mmol $\mathrm{O}_{2} \mathrm{~m}^{-2} \mathrm{~d}^{-1}$ ) over a Posidonia oceanica meadow in the Bay of Revellata at $10 \mathrm{~m}$ bottom depth from 9 August 2006 to 20 August 2007. Solid line indicates the linear regression. Gray dots show raw data, the open circles show the averages by bins. Error bars correspond to standard deviation on the averages by bins.

only contributing to $22 \%$, the rest was contributed by NCP (Fig. 6; Table 1).

The $\mathrm{pCO}_{2}$ data (Fig. 7) allow to compute an atmospheric $\mathrm{CO}_{2}$ sink of $-0.7 \mathrm{~mol} \mathrm{~m}^{-2} \mathrm{yr}^{-1}$ (Supporting Information Fig. S8, Fig. 6). The $P$. oceanica meadow was also a small source of $\mathrm{CH}_{4}$ to the atmosphere at rate of $0.006 \mathrm{~mol} \mathrm{CH}_{4} \mathrm{~m}^{-2} \mathrm{yr}^{-1}$ (Supporting Information Table S3), about 100 times lower than the $\mathrm{CO}_{2}$ sink. Nevertheless, values of $\mathrm{CH}_{4}$ in surface waters were generally much higher than values in surface waters of the open Mediterranean Sea (de la Paz et al. 2015), and seasonal variations seem related to sediment resuspension during winter (Supporting Information Table S3) in relation to storms (Dauby et al. 1995). The comparison of metabolic balance of $\mathrm{CO}_{2}$ and the air-sea $\mathrm{CO}_{2}$ flux is misleading, as these processes are usually uncoupled (Borges et al. 2006). Indeed, the lowest values of $\mathrm{pCO}_{2}$ at in situ sea surface temperature (SST) ( $\left.\mathrm{pCO}_{2} @ S S T\right)$ were observed in April, while the highest $\mathrm{pCO}_{2} @ S S T$ values were observed in August. The $\mathrm{pCO}_{2}$ values decreased regularly from August 2006 to late April 2007, then increased from April to August 2007, following the SST seasonal cycle. This can be explained by temperature effect on Henry's constant (Takahashi et al. 2002). Indeed, $\mathrm{pCO}_{2} @ S S T$ correlated well to SST but with different slopes for period of summer-fall-winter transition and the period of winter-spring-summer transition (Fig. 8). The period of winterspring-summer transition was characterized by $P$. oceanica leaf growth, biomass accumulation and increasing trend in NCP (Fig. 3b) and was characterized by lower $\mathrm{pCO}_{2} @ S S T$ values at a given temperature than for period of summer-fall-winter transition (Fig. 8) that was characterized by $P$. oceanica leaf senescence and decreasing trend in NCP (Fig. 3a). This was consistent with the trends of $\mathrm{pCO}_{2}$ normalized to a constant temperature of $19^{\circ} \mathrm{C}\left(\mathrm{pCO}_{2} @ 19^{\circ} \mathrm{C}\right)$. This normalization removes the effect of temperature on $\mathrm{CO}_{2}$ solubility, consequently, the variations of $\mathrm{pCO}_{2} @ 19^{\circ} \mathrm{C}$ reflect the effect of the other biogeochemical processes (biological activity and/or physical mixing) (Takahashi et al. 2002). Indeed, $\mathrm{pCO}_{2} @ 19^{\circ} \mathrm{C}$ increased during the summerfall-winter transition period (August to late February) and decreased during the winter-spring-summer transition period (early March to late May) (Fig. 7b). Furthermore, $\mathrm{pCO}_{2} @ 19^{\circ} \mathrm{C}$ was significantly negatively correlated to GPP, while $\mathrm{pCO}_{2} @ S S T$ was uncorrelated to GPP, confirming the confounding effect of temperature on $\mathrm{pCO}_{2}$ over biological processes (Fig. 9). Data of $\mathrm{pCO}_{2}$ have also been reported in a $P$. oceanica meadow in the Bay of Palma, and both the $\mathrm{pCO}_{2} @ S S T$ and $\mathrm{pCO}_{2} @ 19^{\circ} \mathrm{C}$ followed the same seasonal pattern as in the Bay of Revellata with lower $\mathrm{pCO}_{2}$ values in spring than summer (Fig. 7a,b). The pCO $\mathrm{pCSST}_{2}$ and $\mathrm{pCO}_{2} @ 19^{\circ} \mathrm{C}$ in the Bay of Palma were higher than in the Bay of Revellata of about 25 ppm and this might reflect the fact that the data in the Bay of Palma were obtained over the full depth range of the meadow (down to about $50 \mathrm{~m}$ bottom depth) while the data in Bay of Revellata were only from $10 \mathrm{~m}$ bottom depth, so the difference might represent spatial variability of surface $\mathrm{pCO}_{2}$ due to seafloor depth. The spatial distribution reported by Gazeau et al. (2005) in the Bay of Palma shows that the $\mathrm{pCO}_{2}$ values over the meadow were $40 \mathrm{ppm}$ lower than the $\mathrm{pCO}_{2}$ values from offshore waters. In addition, the difference might simply be due to different $\mathrm{pCO}_{2}$ value of the offshore water incoming into the bay that sets a "background" $\mathrm{pCO}_{2}$ value that decreases as the water mass travels over the meadow (Gazeau et al. 2005).

In conclusion, the direct comparison of $\mathrm{CO}_{2}$ uptake from community metabolism to air-sea $\mathrm{CO}_{2}$ fluxes is difficult due to additional processes that affect $\mathrm{CO}_{2}$ dynamics, namely, physical processes (water temperature changes, vertical mixing, and water mass horizontal transport). In the case of communities with a low spatial extent and short residence time such as seagrass meadows, community metabolism will only marginally modify the $\mathrm{CO}_{2}$ content of incoming offshore water. The $\mathrm{CO}_{2}$ content of incoming offshore water is probably the most important factor setting the direction and 
intensity of air-sea $\mathrm{CO}_{2}$ fluxes in such marine communities (Gazeau et al. 2005; Borges et al. 2006). In our particular case, air-sea $\mathrm{CO}_{2}$ flux could only balance $2 \%$ of total community net $\mathrm{CO}_{2}$ uptake, and we assume that the majority of total community net $\mathrm{CO}_{2}$ uptake (98\%) was sustained by $\mathrm{CO}_{2}$ from external water masses advected on the meadow (Fig. 6).

\section{Data availability statement}

Data sets are publically available and can be downloaded from zenodo.org (Borges and Champenois 2021).

\section{References}

Adams, M. P., A. J. P. Ferguson, P. S. Maxwell, B. A. J. Lawson, J. Samper-Villarreal, and K. R. O’Brien. 2016. Light historydependent respiration explains the hysteresis in the daily ecosystem metabolism of seagrass. Hydrobiologia 766: 7588. doi:10.1007/s10750-015-2444-5

Apostolaki, E. T., M. Holmer, N. Marbà, and I. Karakassis. 2010. Metabolic imbalance in coastal vegetated (Posidonia oceanica) and unvegetated benthic ecosystems. Ecosystems 13: 459-471. doi:10.1007/s10021-010-9330-9

Atkinson, M. S., and S. V. Smith. 1983. C:N:P: Ratios of bentic marine plants. Limnol. Oceanogr. 28: 568-574. doi:10.4319/lo. 1983.28.3.0568

Bailleul, B., and others. 2015. Energetic coupling between plastids and mitochondria drives $\mathrm{CO}_{2}$ assimilation in diatoms. Nature 524: 366-369. doi:10.1038/nature14599

Baines, S. B., and M. L. Pace. 1991. The production of dissolved organic matter by phytoplankton and its importance to bacteria: Patterns across marine and freshwater systems. Limnol. Oceanogr. 36: 1078-1090. doi:10.4319/lo.1991.36.6.1078

Barrón, C., C. M. Duarte, M. Frankignoulle, and A. V. Borges. 2006. Organic carbon metabolism and carbonate dynamics in a Mediterranean seagrass (Posidonia oceanica) meadow. Estuar. Coasts 29: 417-426. doi:10.1007/BF02784990

Barrón, C., and C. M. Duarte. 2009. Dissolved organic matter release in a Posidonia oceanica meadow. Mar. Ecol. Prog. Ser. 374: 75-84. doi:10.3354/meps07715

Bay, D. 1984. A field study of the growth dynamics and productivity of Posidonia oceanica (L.) Delile in Calvi Bay, Corsica. Aquat. Bot. 20: 43-64. doi:10.1016/0304-3770(84)90026-3

Benson, B. B., and D. Krause Jr. 1984. The concentration andisotopic fractionation of oxygen dissolved in freshwater and seawater in equilibrium with the atmosphere. Limnol. Oceanogr. 29: 620-632. doi:10.4319/1o.1984.29.3.0620B

Borges, A. V., L.-S. Schiettecatte, G. Abril, B. Delille, and F. Gazeau. 2006. Carbon dioxide in European coastal waters. Estuar. Coast. Shelf Sci. 70: 375-387. doi:10.1016/j.ecss.2006.05.046

Borum, J., K. Sand-Jensen, T. Binzer, O. Pedersen, and T. M. Greve. 2006. Oxygen movement in seagrasses, p. 255-270. In A. W. D. Larkum, R. J. Orth, and C. M. Duarte [eds.], Seagrasses: Biology, ecology and conservation. Dordrecht, The Netherlands: Springer.
Borowitzka, M. A., and A. W. D. Larkum. 1981. Calcification in algae: Mechanisms and the role of metabolism. Crit. Rev. Plant Sci. 6: 1-45. doi:10.1080/073526 88709382246

Boudouresque, C. F., and others. 2006. Préservation et conservation des herbiers à Posidonia oceanica. Monaco: Ramoge Publisher, p. 202.

Borges, A. V., and W. Champenois. 2021. Oxygen saturation, water temperature, gross primary production, community respiration, net community production, partial pressure of $\mathrm{CO}_{2}$ over a Posidonia oceanica meadow in the Bay of Revellata (2006-2018). Limnol. Oceangraph. doi:10.5281/ zenodo. 4421348

Brodersen, K. E., S. M. Trevathan-Tackett, D. A. Nielsen, R. M. Connolly, C. E. Lovelock, T. B. Atwood, and P. I. Macreadie. 2019. Oxygen consumption and sulfate reduction in vegetated coastal habitats: Effects of physical disturbance. Front. Mar. Sci. 6: 14. doi:10.3389/fmars.2019.00014

Cebrián, J., and C. M. Duarte. 1998. Patterns in leaf herbivory on seagrass. Aquat. Bot. 60: 67-82. doi:10.1016/S03043770(97)00070-3

Cline, J. D. 1969. Spectrophotometric determination of hydrogen sulphide in natural water. Limnol. Oceanogr. 14: 454458. doi:10.4319/1o.1969.14.3.0454

Champenois, W., and A. V. Borges. 2012. Seasonal and interannual variations of community metabolism rates of a Posidonia oceanica seagrass meadow. Limnol. Oceanogr. 57: 347-361. doi:10.4319/1o.2012.57.1.0347

Champenois, W., and A. V. Borges. 2019. Inter-annual variations over a decade of primary production of the seagrass Posidonia oceanica. Limnol. Oceanogr. 64: 32-45. doi:10.1002/lno. 11017

Dauby, P. 1985. Plankton productivity in gulf of Calvi (Corsica), p. 442-450.In R. Van Grieken and R. Wollast [eds.], Progress in Belgian oceanographic research. Antwerp, Belgium: Antwerp Univ. Press.

Dauby, P., and others. 1995. Particle fluxes over a Mediterranean seagrass bed: A one year case study. Mar. Ecol. Prog. Ser. 126: 233-246. doi:10.3354/meps 126233

de la Paz, M., I. E. Huertas, S. Flecha, A. F. Ríos, and F. F. Pérez. 2015. Nitrous oxide and methane in Atlantic and Mediterranean waters in the Strait of Gibraltar: Air-sea fluxes and inter-basin exchange. Prog. Oceanogr. 138: 18-31. doi:10. 1016/j.pocean.2015.09.009

Del Giorgio, P. A., and P. J. L. B. Williams. 2005. Respiration in aquatic ecosystems. New York, Oxford Univ. Press, p. 315. doi:10.1093/acprof:oso/9780198527084. 001.0001

de los Santos, C. B., and others. 2019. Recent trend reversal for declining European seagrass meadows. Nat. Commun. 10: 3356. doi:10.1038/s41467-019-11340-4

Dickson, A. G. 1993. pH buffers for sea water media based on the total hydrogen ion concentration scale. Deep-Sea Res. 40: 107-118. doi:10.1016/0967-0637(93)90055-8 
Duarte, C. A., and J. Cebrián. 1996. The fate of marine autotrophic production. Limnol. Oceanogr. 41: 1758-1766. doi: 10.4319/lo.1996.41.8.1758

Duarte, C. M., and S. Agustí. 1998. The $\mathrm{CO}_{2}$ balance of unproductive aquatic ecosystems. Science 281: 234-236. doi:10.1126/science.281.5374.234

Duarte, C. M., and D. Krause-Jensen. 2017. Export from seagrass meadows contributes to marine carbon sequestration. Front. Mar. Sci. 4: 1-13. doi:10.3389/fmars.2017.00013

El Haïkali, B., N. Bensoussan, J.-C. Romano, and V. Bousquet. 2004. Estimation of photosynthesis and calcification rates of Corallina elongata Ellis and Solander, 1786, by measurements of dissolved oxygen, $\mathrm{pH}$ and total alkalinity. Sci. Mar. 68: 45-56. doi:10.3989/scimar.2004.68n145

Felisberto, P., and others. 2015. Acoustic monitoring of $\mathrm{O}_{2}$ production of a seagrass meadow. J. Exp. Mar. Biol. Ecol. 464: 75-87. doi:10.1016/j.jembe.2014.12.013

Frankignoulle, M., and J.-M. Bouquegneau. 1987. Seasonal variations of the diel carbon budget of a marine macrophytes ecosystem. Mar. Ecol. Prog. Ser. 38: 197-199. doi:10.3354/ meps038197

Frankignoulle, M., C. Canon, and J.-P. Gattuso. 1994. Marine calcification as a source of carbon dioxide: Positive feedback of increasing atmospheric $\mathrm{CO}_{2}$. Limnol. Oceanogr. 39: 458-462. doi:10.4319/1o.1994.39.2.0458

Gacia, E., N. Marbà, J. Cebrián, R. Vaquer-Sunyer, N. GarciasBonet, and C. M. Duarte. 2012. Thresholds of irradiance for seagrass Posidonia oceanica meadow metabolism. Mar. Ecol. Prog. Ser. 466: 69-79. doi:10.3354/meps09928

Gattuso, J.-P., M. Frankignoulle, and R. Wollast. 1998. Carbon and carbonate metabolism in coastal aquatic ecosystems. Annu. Rev. Ecol. Syst. 29: 405-434. doi:10.1146/annurev.ecolsys.29.1.405

Gazeau, F., and others. 2005. Whole system metabolism and $\mathrm{CO}_{2}$ fluxes in a Mediterranean Bay dominated by seagrass beds (Palma Bay, NW Mediterranean). Biogeosci. 2: 43-60. doi:10.5194/bg-2-43-2005

Glud, R. N., J. K. Gundersen, B. B. Jørgensen, N. P. Revsbech, and H. D. Schulz. 1994. Diffusive and total oxygen uptake of deepsea sediments in the eastern South Atlantic Ocean: In situ and laboratory measurements. Deep Sea Res I 41: 1767-1788. doi: 10.1016/0967-0637(94)90072-8

Ho, D. T., C. S. Law, M. J. Smith, P. Schlosser, M. Harvey, and P. Hill. 2006. Measurements of air-sea gas exchange at high wind speeds in the Southern Ocean: Implications for global parameterizations. Geophys. Res. Lett. 33: L16611. doi:10. 1029/2006GL026817

Holmer, M., F. Ø. Andersen, N. Holmboe, E. Kristensen, and N. Thongtham. 1999. Transformation and exchange processes in the Bangrong mangrove forest-seagrass bed system, Thailand. Seasonal and spatial variations in benthic metabolism and sulfur biogeochemistry. Aquat. Microb. Ecol. 20: 203-212. doi:10.3354/ame020203

Holmer, M., C. M. Duarte, and N. Marbá. 2003. Sulfur cycling and seagrass (Posidonia oceanica) status in carbonate sediments. Biogeochemistry 66: 223-239. doi:10.1023/B: BIOG.0000005326.35071.51

Howard, J. L., J. C. Creed, M. V. P. Aguiar, and J. W. Fouqurean. 2018. $\mathrm{CO}_{2}$ released by carbonate sediment production in some coastal areas may offset the benefits of seagrass "Blue Carbon" storage. Limnol. Oceanogr. 63: 160-172. doi:10.1002/lno.10621

Jacquemart, J., and V. Demoulin. 2006. Inventaire des macroalgues éphiphytes des feuilles de Posidonia oceanica (L.) Delile dans la baie de la Revellata (Calvi, Corse). Lejeunia 181: 70 .

Knap, A. H., A. E. Michaels, A. Close, E, H.W. Ducklow and A. G. Dickson, 1996. Protocols for the Joint Global Ocean Flux Study (JGOFS) core measurements. Bergen, Norway, UNESCO. JGOFS Report no. 19. Available from http:// ijgofs.whoi.edu/Publications/Report_Series/JGOFS_19.pdf

Koopmans, D., M. Holtappels, A. Chennu, M. Weber, and D. de Beer. 2020. High net primary production of Mediterranean Seagrass (Posidonia oceanica) meadows determined with aquatic Eddy covariance. Front. Mar. Sci. 7: 1-13. doi: 10.3389/fmars.2020.00118

Langdon, C., and others. 2000. Effect of calcium carbonate saturation state on the calcification rate of an experimental coral reef. Global Biogeochem. Cycles 14: 639-654. doi:10. 1029/1999GB001195

Long, M. H., K. Sutherland, S. D. Wankel, D. J. Burdige, and R. C. Zimmerman. 2020. Ebullition of oxygen from seagrasses under supersaturated conditions. Limnol. Oceanogr. 65: 314-324. doi:10.1002/lno.11299

Long, M. H., P. Berg, and J. F. Falter. 2015. Seagrass metabolism across a productivity gradient using the eddy covariance, Eulerian control volume, and biomass addition techniques. J. Geophys. Res. 120: 3624-3639. doi:10.1002/ 2014JC010352

Marañón, E., P. Cermeno, E. Fernández, J. Rodriguez, and L. Zabala. 2004. Significance and mechanisms of photosynthetic production of dissolved organic carbon in a coastal eutrophic ecosystem. Limnol. Oceanogr. 49: 1652-1666. doi:10.4319/lo.2004.49.5.1652

Marbà, N., M. Holmer, E. Gacia, and C. Barron. 2006. Seagrass beds and coastal biogeochemistry, p. 135-157.In A. W. D. Larkum, R. J. Orth, and C. M. Duarte [eds.], Seagrasses: Biology, ecology and conservation. Dordrecht, The Netherlands, Springer. doi:10.1007/978-1-4020-2983-7_6

Martin, S., A. Charnoz, and J.-P. Gattuso. 2013. Photosynthesis, respiration and calcification in the Mediterranean crustose coralline alga Lithophyllum cabiochae (Corallinales, Rhodophyta). Eur. J. Phycol. 48: 163-172. doi:10.1080/ 09670262.2013.786790

Mateo, M. A., J. Romero, M. Pérez, M. M. Littler, and D. S. Littler. 1997. Dynamics of millenary organic deposits resulting from the growth of the Mediterranean seagrass Posidonia oceanica. Estuar. Coast. Shelf Sci. 44: 103-110. doi:10.1006/ecss.1996.0116 
Mateo, M. A., P. Renom, M. A. Hemminga, and J. Peene. 2001. Measurement of seagrass production using the ${ }^{13} \mathrm{C}$ stable isotope compared with classical $\mathrm{O}_{2}$ and ${ }^{14} \mathrm{C}$ methods. Mar. Ecol. Prog. Ser. 223: 157-165. doi:10.3354/meps223157

Mazzella, L., M. B. Scipione, and M. C. Buia. 1989. Spatiotemporal distribution of algal and animal communities in a Posidonia oceanica meadow. Mar. Ecol. 10: 107-129. doi:10. 1111/j.1439-0485.1989.tb00069.x

Mehrbach, C., C. H. Culberson, J. E. Hawley, and R. M. Pytkowicz. 1973. Measurements of the apparent dissociation constants of carbonic acid in seawater at atmospheric pressure. Limnol. Oceanogr. 18: 897-907. doi:10.4319/lo. 1973.18.6.0897

Morana, C., H. Sarmento, J.-P. Descy, J.-M. Gasol, A. V. Borges, S. Bouillon, and F. Darchambeau. 2014. Production of dissolved organic matter by phytoplankton and its uptake by heterotrophic prokaryotes in large tropical lakes. Limnol. Oceanogr. 59: 1364-1375. doi:10.4319/lo.2014.59.4.1364

Moriarty, D. J. W., R. L. Iverson, and P. C. Pollard. 1986. Exudation of organic carbon by the seagrass Halodule wrightii Aschers and its effect on bacterial growth in the sediment. J. Exp. Mar. Biol. Ecol. 96: 115-126. doi:10.1016/00220981(86)90237-6

Moulin, E., A. Jordens, and R. Wollast. 1985. Influence of the aerobic bacterial respiration on the early dissolution of carbonates in coastal sediments, p. 196-208. In R. Van Grieken and R. Wollast [eds.], Progress in Belgian Oceanographic Research: Proceedings of a symposium held at the Palace of Academies Brussels. 3-5 March 1985. Antwerp Univ. Press. Antwerp, Belgium.

Noguchi, I., and K. Yoshida. 2008. Interaction between photosynthesis and respiration in illuminated leaves. Mitochondrion 8: 87-99. doi:10.1016/j.mito.2007.09.003

Odum, H. T. 1956. Primary production in flowing waters. Limnol. Oceanogr. 1: 102-117. doi:10.4319/lo.1956.1.2.0102

Penhale, P. A., and W. O. Smith. 1977. Excretion of dissolved organic carbon by eelgrass (Zostera marina) and its epiphytes. Limnol. Oceanogr. 22: 400-407. doi:10.4319/lo. 1977.22.3.0400

Pergent, G., and C. Pergent-Martini. 1991. Leaf renewal cycle and primary production of Posidonia oceanica in the bay of Lacco Ameno (Ischia, Italy) using lepidochronological analysis. Aquat. Bot. 42: 49-66. doi:10.1016/0304-3770(91)90105-E

Rasmusson, L. M., and M. Björk. 2014. Determining light suppression of mitochondrial respiration for three temperate marine macrophytes using the Kok method. Bot. Mar. 57: 483-486. doi:10.1515/bot-2014-0046

Smith, S. V., and G. S. Key. 1975. Carbon dioxide and metabolism in marine environments. Limnol. Oceanogr. 20: 493495. doi:10.4319/lo.1975.20.3.0493

Takahashi, T., and others. 2002. Global sea-air $\mathrm{CO}_{2}$ flux based on climatological surface ocean $\mathrm{pCO}_{2}$, and seasonal biological and temperature effects. Deep-Sea Res. II 49: 1601-1622. doi:10.1016/S0967-0645(02)00003-6
Telesca, L., and others. 2015. Seagrass meadows (Posidonia oceanica) distribution and trajectories of change. Sci. Rep. 5: 12505. doi:10.1038/srep12505

Trevathan-Tackett, S. M. 2017. Sediment anoxia limits microbial-driven seagrass carbon remineralization under warming conditions. FEMS Microbiol. Ecol. 93: others. doi: 10.1093/femsec/fix033

Van Dam, B. R., C. Lopes, C. L. Osburn, and J. W. Fourqurean. 2019. Net heterotrophy and carbonate dissolution in two subtropical seagrass meadows. Biogeosciences 16: 4411-4428. doi:10.5194/bg-16-4411-2019

van der Heijden, L. H., and N. A. Kamenos. 2015. Reviews and syntheses: Calculating the global contribution of coralline algae to total carbon burial. Biogeosciences 12: 6429-6441. doi:10.5194/bg-12-6429-2015

Velimirov, B., and others. 2016. Estimating carbon fluxes in a Posidonia oceanica system: Paradox of the bacterial carbon demand. Estuar. Coast. Shelf Sci. 171: 23-34. doi:10.1016/ j.ecss.2016.01.008

Weiss, R. F., and B. A. Price. 1980. Nitrous oxide solubility in water and seawater. Mar. Chem. 8: 347-359. doi:10.1016/ 0304-4203(80)90024-9

Wilson, S. T., and others. 2018. An intercomparison of oceanic methane and nitrous oxide measurements. Biogeosciences 15: 5891-5907. doi:10.5194/bg-15-5891-2018

Yates, K. K., and R. B. Halley. 2006. Diurnal variation in rates of calcification and carbonate sediment dissolution in Florida Bay. Estuar. Coasts 29: 24-39. doi:10.1007/BF02784696

Zieman, J. C. 1974. Methods for the study of the growth and production of turtle grass, Thalassia testudinum konig. Aquaculuture 4: 139-143. doi:10.1016/0044-8486(74) 90029-5

\section{Acknowledgments}

We thank P. Lejeune and the STARESO team for logistical support, L.-S. Schiettecatte for help in sampling during the first year of the time series, B. Delille for help in setting up the Pro-oceanus, C. Champenois and M.-V. Commarieu for support during the underwater dives, the Oceanology Laboratory (ULiège) for lending the incubation chambers and water pumps, an anonymous reviewer and associate editor for suggestions that helped to improve the previous version of the manuscript. This work was funded by the Fonds National de la Recherche Scientifique (FNRS) (contracts F.4513.06, 2.4.511.09 and 2.4.637.10) and the Territorial Collectivity of Corsica and the Rhone-Mediterranean and Corsica Water Agency (STARE-CAPMED-Station of reference and research on change of local and global anthropogenic pressures on Mediterranean ecosystem drifts). A.V.B. is a research director at the FNRS and co-first author.

\section{Conflict of Interest}

None declared.

Submitted 06 July 2020

Revised 08 January 2021

Accepted 18 January 2021

Associate editor: Robinson Fulweiler 